\title{
APPROACH TO HYGIENIC WATER AND CLEANLINESS FACILITIES FOR RURAL UGANDANS
}

\author{
S M Nazmuz Sakib \\ Graduate of BSc in Business Studies \\ School of Business And Trade \\ Pilatusstrasse 6003, 6003 Luzern, Switzerland \\ sakibpedia@gmail.com \\ Student of Department of Law \\ Dhaka International University \\ House \# 4, Road \# 1, Block - F, Dhaka 1213 \\ sakibpedia@students.diu.ac \\ Student of BEcon in Environmental and Resource Economics \\ Dhaka School of Economics \\ 4/C Eskaton Garden Rd, Ramna, Dhaka 1000, Bangladesh. \\ sakib.bee5@dsce.edu.bd
}




\section{ABSTRACT}

This research contributes to the detailed discussion about the approach to secure, hygienic water and cleanliness in Uganda and its pastoral regions. The relationship between the sanitation and clean water access with destitution is also discussed. Although this document is not leading towards the policy recommendation but it is an overall idea of how Uganda progressed because of the provisions adopted by the government, local and international organizations, and NGOs, and how the country lacked before these steps taken. Most of the data mentioned is taken from the house surveys of a decade 2002-2013 alongside the qualitative data. Literature review is also considered and is divided in two sections: first included researches related to water accessibility and usage, while the second section included researches related to work done and progress for diarrheal diseases and sanitation. Afterwards, methodologies were discussed where, firstly, trends and then the limitations in access to the basic necessities of life that is clean water and hygiene are mentioned. At last, the implementations and how they affected the rural Ugandans was discussed.

\section{Keywords}

Hygiene, Cleanliness, Water, Rural water facility, Water shortage, Uganda 


\section{ABBREVIATIONS \& ACRONYMS}

UN

UNGA

W H O

SDG's

AIDS

HIV

NGO

COWESER

NETWAS

UMURDA

JESE

WUC

SDW

WUC

CBM

WPC's

O\&M

NWSC

JMP

USAID

WWB

\section{United Nations}

United Nations General Assembly

World Health Organization

Sustainable Development Goals

Acquired Immunodeficiency Syndrome

Human Immunodeficiency Virus

Non-Government Organizations

COmmunity WElfare SERvices

NETwork for Water and Sanitation

Uganda MUslim Rural Development Association

Joint Effort to Save the Environment

Water User's Community

Shared Dialogue Workshop

Water User's Committees

Community-Based Management

Water Point Committees

Operation and Maintenance

National Water and Sewerage Company

WHO UNICEF Joint Monitoring Program for Water \& Sanitation

United Sates Agency for International Development

World Without Borders (International Organization) 


\section{CHAPTER 1}

\section{BACKGROUND}

\subsection{Introduction}

Approach to clean, maintainable water and hygiene prerequisites are arguably amongst the most enduring provocations emergent countries face, as an ever-growing populace colonize those countries. The United Nations assesses that a population of almost one billion people endure a shortage of clean water prerequisites and about 2.2 billion don't have essential hygiene facilities planetary. The circumstance in pastoral Uganda sticks to this pattern since a major populace is composed of sharecroppers living in pastoral regions away from the big towns.

This research probes the link between approach to water and hygiene prerequisites and health ameliorations in pastoral Uganda. The subsequent segments will emphasize on the territorial, traditional, and communal facets which are crucial to understand the causes of ignorance of a major populace of pastoral Ugandans and their lives in such desperate circumstances with zero or contaminated water dispense and have no hygiene prerequisites. Is it so, as there is deficiency of the most suitable gadgets for that region or inadequate capitals or lack of healthy superintendence or is it just the reason of the incomprehension of superiors? The focal point of this paper is Kalisizo, present in the Rakai District, and the area that suffered the most.

\subsection{Objectives \& Aims of the Analysis}

This research basically targets at examining and evaluating the basis behind the inadequacy of pristine and drinking water and the viability of an eco-friendly hygiene system in Rakai, and hence at controlling a secure and clean substitute that is both eugenically and ethically admissible alongside for the provision for the people of Rakai.

The major aim of this dissertation was to gather enough details and many experiences grasped from researches to find out rational and logical solutions within the sort of technicalities to improve the society. Moreover, distinguishing the eugenic and ethical facets that can affect the parts of sufficiency, functionality, sustainability, and duplication of the advancements.

\subsection{Findings (Questions)}

This study aims to address queries like: 
- What is the power beyond the circumstances in the region?

- Is the structure appraisable by the inhabitants of Rakai?

- What are the provocations that need to be bridled to ameliorate the sanitation structure and its aptitude benefactions to the society in unison?

- Is this a literature-based dissertation?

These questions are being answered throughout the paper efficiently and quite thoroughly.

\subsection{Geography and Natural Resources}

Uganda is amongst the 44 landlocked countries, located in East-Central Africa. It is a not so large country covering about 241,038 square $\mathrm{km}$ and giving a hostage to $147,123,531$ people. Although these people do not enjoy the sea but have about four rivers namely: Lake Victoria, Lake Albert, Lake Edward, and Lake Kyoga. Near Jinja (one of its cities) Uganda spots the location where the river Nile decants to Lake Victoria. Since it spans over the equator and so, Ugandans enjoy mild tropical climate conditions. While being on $1.2 \mathrm{~km}$ of altitude, the average temperature lies between 15 and 30 Celsius. Despite high precipitation, during the two rainy seasons (October - December, March-May) 1.2 meters yearly rainfall is normal around the country. The highest mountains of the country are Mount Elgon about 4321 meters high and the Rwenzori about 5109 meters. Mount Elgon lies in the East while the latter one in the West and so is snow-capped. Other than that, most of the country is grassy flat or scarce forests including tropical rainforest specks in the national parks. The drainage system within the country is pathetic with papyrus marshlands furnishing adequate abodes or habitats all over the country.

Uganda is considered one of the most key fauna abodes for a vast range of organisms. The civic playgrounds from the westward part are quite known for the lions, elephants, hippopotamuses, zebras, various antelopes, buffaloes, and other wild animals like these. Anthropoid family including monkeys, lemurs, monks, and almost $50 \%$ of the earth's mountain gorillas is also found in a large amount. 


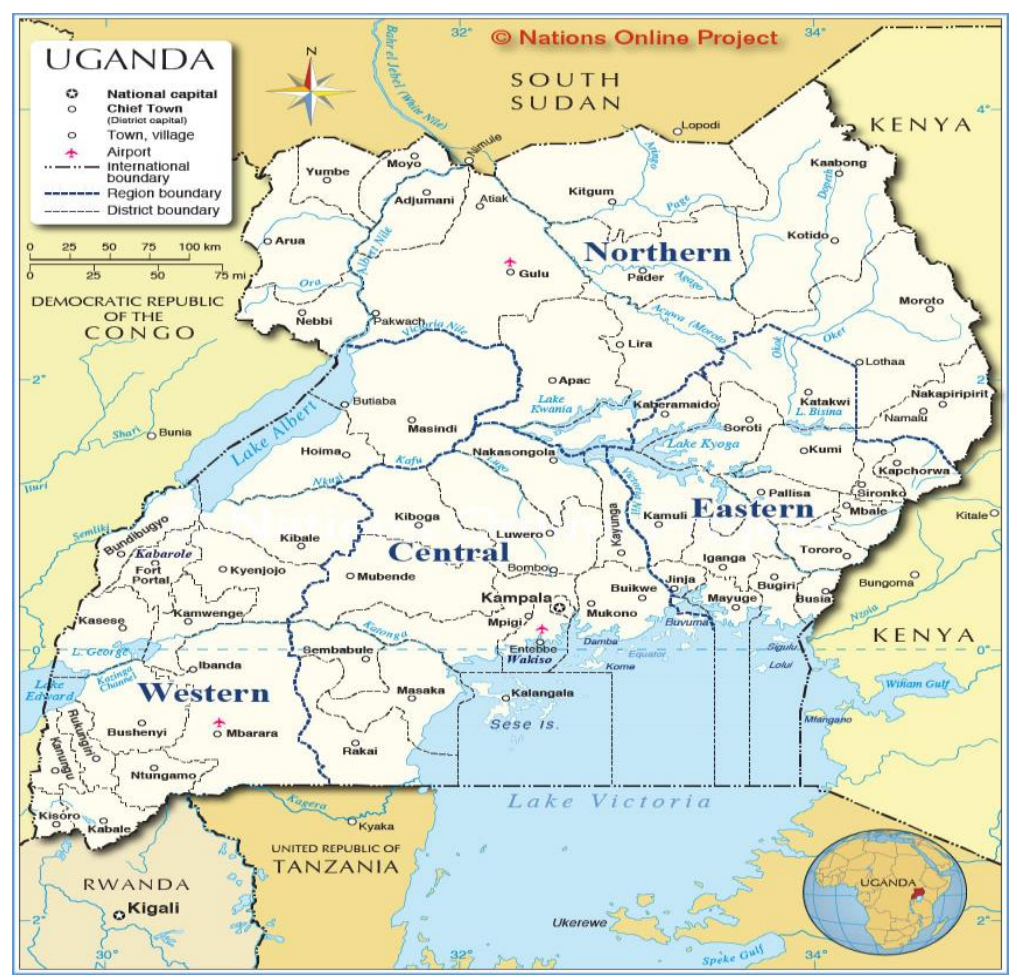

Figure I Administrative Map of Uganda

Figure i-a: Administrative Map of Uganda

\subsection{Cultural and Linguistics}

Uganda is a diverse country in terms of languages. It bags about thirty various languages alongside thirty ethnicities. Nilotic and Bantu are the major two language classes of Uganda. The people who follow Nilotic class of language reside in Northern areas of Lake Kyoga, while Southern areas consist of the people following Bantu language.

\subsection{Rakai Region \& Kalisizo Town}

The details written in this document are mostly accomplished in Kalisizo Town unearthed in Rakai Region, about $160 \mathrm{~km}$ south of Kampala besides a concreted roadway. The region, adjoining the Tanzanian boundary to the south, and Lake Victoria to the east is 4,989 square kilometers and is embraces over 500,000 people with a yearly development estimate of about $3.2 \%$, overcrowding is a sempiternal issue. The region, like most of the country, collects enough cloudbursts and includes grassy hills scattered with various mush lands and a bit of 
jungles.

Almost 70\% populace is sharecroppers farming primary culls such as bananas, maize, batatas, and cowpea. This food is augmented with sectionally harvested crisp bear fruits like pineapples, jackfruit, mangoes, and avocados alongside tomatoes and greens. Beef, chicken, beans, and fish are the major sources of polypeptides harvested near Lake Victoria. Many clans reside in unadorned homes made with sludge, rocks, or stone walls. A number of coastal trawling groups majorly involving agricultural laborers and substantial conurbations, succoring as predominant trades and mercantile epicenters.

A number of healthcare units, hospitals, and clinics are located in the country that alongside the NGOs (Non-Government Organizations) work to impart basic health convenience to the Ugandans. Despite all these things the quantity and the quality of these services are far less than the required for maintenance of a healthy society.

Large families incorporate in a single house of the country. The average fertility rate per woman is almost 6.5 ending up in poor economic conditions. The residence of the families is the multigenerational compound. However, education is important to them. Considering free primary education, the enrollment for it is $82 \%$, while secondary school is purely for the elite class of Uganda because of the high fees.

\subsection{Non-Government Organizations (NGO's) and Water Usage Survey}

About 14027 NGOs have been registered in Uganda out of which 2119 have been permitted to function following the authentication exercise that started in November 2018 and ended in October 2019. The remaining 11908 NGOs are not allowed to function and hence are closed. NETwork for Water and Sanitation in Uganda spotted three different NGOs in late 2008 that functioned in three different water-stressed zones of the country. All of the three were entirely functional, giving outputs. Amongst the three Uganda MUslim Rural Development Association was active in the east most regions of Bugiri. Open Palm COmmunity WElfare SERvices was found operational in the primary regions of Rakai. While Joint Effort to Save the Environment functioned for the western region of Kamwenge. All the areas show variety in the languages, tribes, and even cultures. The similarities that can be navigated are of climate with regular daily 
temperatures of around 20-30 Centigrade and two damp periods per year for three months.

\section{CHAPTER 2}

\section{LITERATURE REVIEW}

This research describes the private manipulation of water in pastoral Uganda alongside venturing to track down the reasons and then curing the inadequacy of water and asepsis privilege because of which majority areas of Uganda is dolouring. As a preparatory stride in the detailed study, certain relevant publications are broached condensing the prevailing compositions on the below mentioned topics.

\subsection{Water Approachability and Utilization}

A fundamental query in the growing tasks is knowing about the quantity of water needed by the inhabitants in order to live and how much this amount alters as the water wellsprings come closer to their home places making fetching much more convenient and flexible. The most important project on this matter is a study by (Howard, Bartram et al. 2020). The research, written for the World Health Organization (WHO), notes rudimentary human water needs taking help from the previous researches making connections between water and hygiene conducts and ameliorated fitness. Authors specify four ministration extents and contend that because of these mentioned ministration extents the advantages and the genuine quantity of water which is required is not broached till date.

Furthermore, the amount of water utilized for the sake of cleaning and laving is exceptionally delicate for ministration levels. People who need to move more than 1 kilometer to fetch water avoid using water for the cleaning and laving purposes.

The major force of this study was served in explaining water approachability with regards to water amenity segments rather than the genuine amount measured in liters. Table 2.1 abridges 
these segments. Table divides the ministration extents with regards to 'Zero Approach,' 'Rudimentary Approach,' 'Median Approach' and 'Ideal Approach' throughout the usage by people, generally 5, 20, 50, and 100 liters per person per day. Those with 'Zero Approach' need to move more than 1 kilometer or about 30 minutes to have water, while people having 'Rudimentary Approach' require a range of five to thirty minutes. At last, people having 'Median Approach' have to travel in or just very near to their houses taking even less than five minutes to fetch it, and people with 'Ideal Approach' are enjoying more than one spouts within their homes. Afterwards, the writers mention that majority people's health profits can happen in two augmentations. First one is to cut down inadequacy of fundamental approach for the houses rarely enjoying adequate water for private utilization and hence, lacking in private hygiene. Furthermore, when households have approach at basic levels, their fitness benefits improve, and get much time for tasks including babysitting, education, or other demographic ventures. At last, it is mentioned that same amount of heed should be paid to both, the provision of water and hygiene that eases the approach to ameliorated wellsprings in extramural will suffer from calculated health issues.

Besides, when the water fetching time reduced from 5 hours to 10 minutes, utilization ameliorated from 4.1 to 11.1 liters per day, with $70 \%$ of the auxiliary water utilized in toilets and other washing causes. Beyond $50 \%$ of the secured time was consumed on fertile house chores.(Cairncross and Cuff 1987)

Cairncross and Feachem (Cairncross and Feachem 1993) assert that if water huddling time increases a little more minutes the water quantity utilization reduces considerably and evens out. This evening out endures from fetching periods of 5 minutes to half an hour and ranges of 100 to 1000 meters.

Another study was finished in Jinja, Uganda regarding water manipulation intensities for different ministration extents. It amplifies the previous works mentioning that houses utilizing common water wellsprings including springs or impulse-pumps utilize approximately 15.8 liters per day. And houses that utilize common stand-posts utilizes approximately 15.5 liters per day, while usage potencies ameliorated dramatically for the clans with spouts in their homes 
(50 liters per day) and those having several links in their homes (155 liters per day).(WELL. and Development 1998)

Another research analyzed the utilization of water and the after effects on it of that water. A day was spent dawdled in every house of DOW 1, where they perceived the surroundings and took certain interviews. Quantity of water that was utilized was documented as well besides the illness, usage of toilets, water wellsprings and the circumstances. (Tumwine, 2002)

Another paper purified the basic facets of maintainability in water and hygiene, in order to examine the main hurdles while setting up those facets. Moreover, proposing certain practicable fixes in surpassing the hurdles. In order to spot the major facets, needed and general maintainability components for pastoral water and hygiene grants from the previous researches. (2009)

A paper by Richmond and Myers culminates that casual agreements are amongst the crucial components for the region. Still pathetic organization generates threats resulting increased susceptibility. (Richmond, Myers et al. 2018)

Research by Marks and Clair-Caliot shows that small regions are not even different when compared to each other but also they are quite sundry as compared to their managerial limits demarcating those regions. It is more because, these regions gather the characteristics of both pastoral and the metropolitan areas.(Marks, Clair-Caliot et al. 2020)

Marijani's research shows that the fragmentation rectifications are the findings of the changes made in the structures and they have quite convincingly modified and improved different parts for the government hierarchy of health and water institutes. Moreover, groups took part in the financial and physical activities regarding health and water diligently. Besides that, investigating their health and water requirements, and many other such activities was also part of those functions in which groups were active.(Marijani 2017)

\subsection{Work Done \& Progress for Diseases and Sanitation}

Southern Uganda's district Lwengo was studied for this paper. Alongside the shared dialogue workshop (SDW), 642 households across seventeen villages were selected randomly. Results showed that $41.7 \%$ of households utilized vulnerable sources while about $30 \%$ of the households had membership in WUC. $52 \%$ of them never contributed financially to WUC, and $34.6 \%$ did contribute on impromptu terms. A relationship between financial contributions, participation, and movements is finely studied in this research. Mobilization did not impact the 
financial contributions after the chi-square test. Knowing that these families paid now and then more specifically when the root broke down. Moreover, it could clearly be seen that the families who made those contributions were nonetheless the same as relatively broke families, indicating that many factors influence these decisions. Most of the time NGOs or the project staff provided the maintenance and operation of the minor steps needed to take to repair the water points. After taking a look at the conditions of the country that is all those disserted bores, dearth of rehab centers and the activities taking place, and definitely the extreme deficiency of zeal and zest for taking steps to improve the technical, financial, and governmental performances, needs to be upgraded. (Etongo, Fagan et al. 2018)

A multi-country study was done which suggested that in order to reduce the diseases caused by unhygienic water such as diarrhea the sanitation conditions must be improved. Just by improving the conditions of water cannot act efficiently. Better water and sanitation facilities combined produce effective results. This research was done in 1996 by Esrey saying that water refinements must be adequate enough to get effective health. Smaller level improvements have no gain. It was also noted that organisms that are found in conventional water supplies are able to fight against pathogens. At last, it was also stated that the BMI that is weight and heights of children can represent better health.(Esrey and Habicht 1986)

Fewtrell (Fewtrell, Kaufmann et al. 2005) composed the most inclusive survey composition. They divided up 46 studies into several categories like cleanliness, sanitation, latrines, water supplies, quality of water, health education, and several other intercessions. The results of this study are summed up in figures 2.2 and 2.3. How a disease varies as exposed to the imperil facets and what risks a disease can result in are termed as relative risk, which is explained in the report. In quantitative words, relative risk can be defined as the ratio of the probability of a happening taking place in intercessions versus when intercessions are not taking place.

$$
R R=\frac{p_{\text {intervention }}}{p_{\text {no-intervention }}}
$$

Where $p_{\text {intervention }}$ and $p_{n o}$-intervention depict the probabilities of the two events.

$$
p_{\text {exposed }}=\frac{a}{a+b}
$$


And

$p_{\text {non-exposed }}=\frac{c}{c+d}$

\section{Diarrhea Found Diarrhea Not Found}

$\begin{array}{lll}\text { Interventions Present } & \mathrm{a} & \mathrm{b} \\ \text { Interventions Absent } & \mathrm{c} & \mathrm{d}\end{array}$

Fewtrell modified two graphs in figures 2.2 and 2.3. Figure 2.2 outlines the survey between dissimilar water and hygiene intercessions in spell of comparative threats. Cleanliness intercessions including hand-washing and educational outbreaks evinced to be much effective as compared to the water-supply intercessions. Output rather showed maximum uncertainties making it even difficult to get any concrete conclusions. The latter graph made a comparison of three different researches including Fewtrell, Esrey et al. and Curtis and Cairncross. This study again stated that hygiene intercessions are proved to be more efficient than the watersupply intercessions. Hence, "What Works Best in Diarrhea Prevention" made a replacement of what works best.
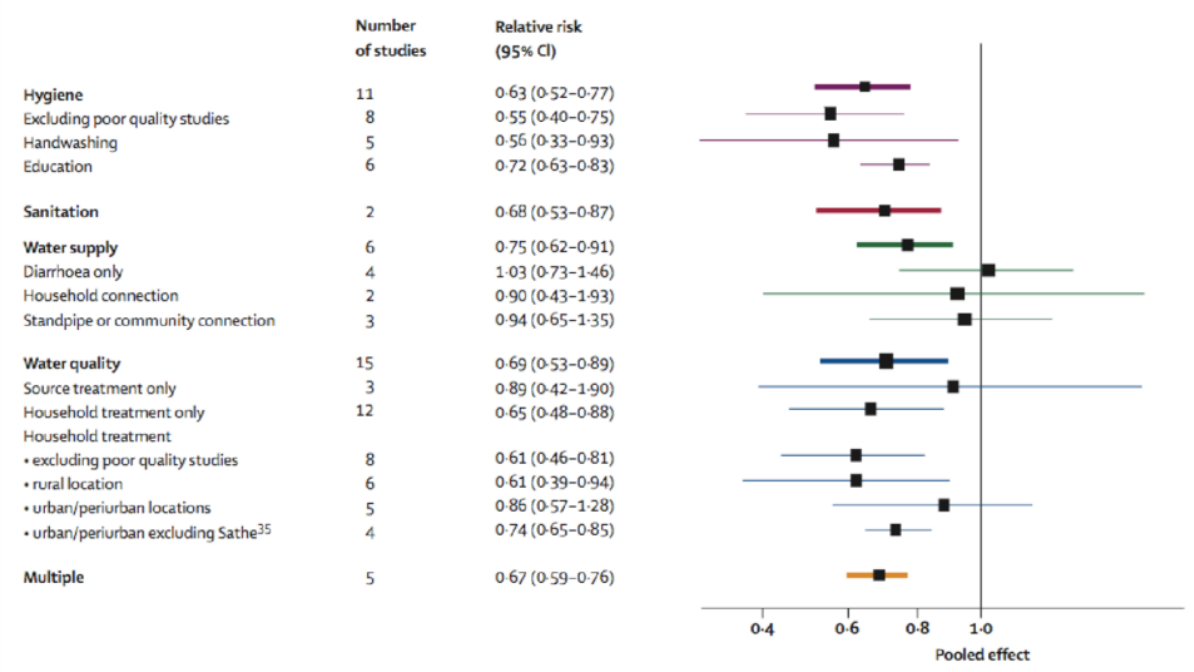

Figure II Comparative threat of the several intercession schemes as collated by Fewtrell et al.

Figure ii-b: Comparative threat of the several intercession schemes as collated by Fewtrell et al. 


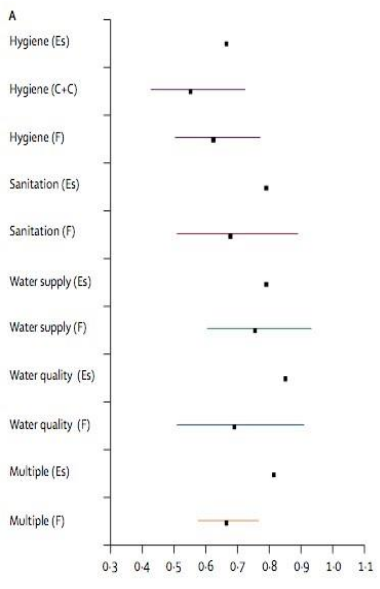

(a)

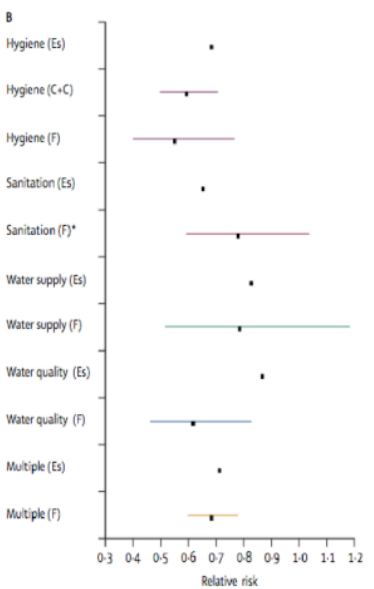

(b)

Figure III A contrast of the Fewtrell research with previous researches by Esrey et al and Curtis and Cairncross (a) All studies and (b) rigorous studies.

How developing countries use a number of sources in order to fight against the diarrheal diseases was studied deeply by Zwane (Zwane and Kremer 2007). This paper revealed that strategies like water piping, sanitary projects, point-of-use water treatment systems and oral rehydration therapies are the steps that can be taken to improve the health and reduce diarrheal diseases to much extent. Although they stated that previous papers suggested communal water supplies to be better for improving health but had methodological shortcomings. These shortcomings are true when programs avoid sanitation improvements.

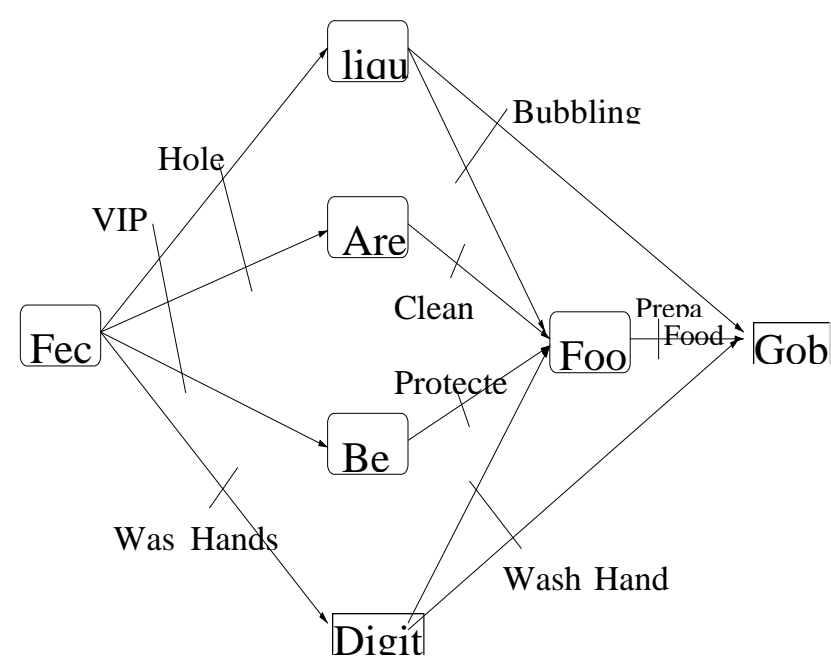

Figure IV The F-diagram conveying the fundamental techniques by which excretions from an individual, passes through the surroundings, and into the gob of another. Hurdles hampering this procedure can be divided as original and subordinates' hurdles. 
Uganda's Community-based management (CBM) prototype works on the theme that when water point committees (WPCs) will be operational (that is they encounter quite frequently, gather funds that are then used by operation and maintenance (O\&M), other than that they also assure kosher sanitation and cleanliness at the sources of water, narrate or control the malfunctions of the hand pumps, and also compose and impose bye-laws) high extents of operational durability of sources of water are realized, meeting high gain, fairness and coherent standards. The training done by the members of the water point committees working in rural areas of Uganda will show the capacity burgeoning of the paper other than the extent of the committees to hold meetings in order to deal with the water-related issues. (Mugumya 2013)

Next research describes the way through which channeled water and the drain water were send to the sewerage communities. Though all these communities were financially stable, but the intrinsic attributes were the basic problem causing. (Nilsson, 2006)

\section{Chapter 3}

\section{METHODOLOGIES}

\subsection{CLEAN WATER}

Secure and easily available water is a vital need of people for their well-being and safety. It is either utilized to drink, for household purposes, preparing food or for any recreational purposes. Better provision of water and sanitary facilities alongside feasible usage of water resources can surely enhance any country's economy and hence can put up for poverty pruning. UNGA distinctly conceded the fundamental privilege for every person to pristine water and public welfare. Every single person has the privilege to adequate, uninterrupted, secure, sustainable, corporeally approachable, and inexpensive water for one's private and domiciliary use.

\subsubsection{Drinking Water Premises with respect to W H O}

SDG that is sustainable development goal earmarks 6.1 exclaims the worldwide impartial approach to conservative, inexpensive, and secure water. The earmark was trailed with the index of "safely managed drinking water services". So, in clear words we can represent this earmark in words like, imbibing water from an ameliorated water wellspring that is tracked down in the central areas, and free of any sort of excretions and chemical contagions. 
5.3 billion people used cautiously supervised drinking water ministrations as reported in 2017 . Other 2.2 billion people who did not enjoy these facilities included:

- 1.4 billion people having improved water wellspring at a walking distance of 30 minutes

- 206 million people having improved water wellsprings at a distance of more than 30 minutes to fetch water

- 435 million people were those who collected water from unprotected wellsprings like springs or wells.

- 144 million people were even in a devastated condition, forced to fetch water from untreated wellsprings like lakes, ponds, rivers or streams

These economic, territorial and sociocultural disproportions not only persist in rural or urban areas but towns and cities are also affected by them. As a global body on people's health and water quality, WHO leads guides the worldwide efforts at a front foot in order to stop the usage of afloat malfunctions, while counselling the governments on the evolution of health-based earmarks.

\subsubsection{Water Crisis and Uganda}

About 51\% people of Uganda that is more than 21 million population is not having the availa bility of clean drinking water.Unfortunately, the trouble is not water. It is just that water predi cament is indissoluble from the hygiene or the purity predicaments. Three factors are strongly influencing healthnamely WASH i.e. water, sanitation and hygiene.

Uganda is standing back for the clean water and hygiene predicaments and so is building a str ong basis but still they need to flourish. Ugandan state is expanding and transitioning and on $\mathrm{t}$ he same note, people are also rebelling to the provocations to erect finer lifestyle.

Following are certain facts and figures that highlight Uganda's crisis about water.

\section{- Majority of the People cannot Approach Unsullied Water}

Organizations like the JMP, UN, and WHO worked together to surveil water, and the hygiene process. They revealed that about $19 \%$ of Ugandans just lean on untreated exterior water for living purposes. These figures estimate that 8 million population is using water through open sources like streams, hand-

dug wells, watercourse or ponds, etc. This unclean water is utilized for drinking, washing, co 
oking in short for every purpose.

Other than that about $32 \%$ population is exposed to lean access to water or we can say that th ey require a distance of 30 minutes to fetch clean water. This happens because of overcrowdi ng or distance.

Summing up there are almost 21 million people who do not even have an approach to safe an d clean water.

\section{- Drifts in Approach to Water Wellsprings}

Below are some trends that used some surveys from the representatives at national level. Although an extension in the NWSC's network occurred in 2012-2013 other than the water expediencies in compact regions under the superintendence of the Ministry of Water \& Environment. According to this survey just $7 \%$ families were using channeled water. As contemplated, channeled water indemnity rate is too high among the clans at hand the best welfares fifths as compared to the poor, as interrelations are dense in towns like Kampala or other crowded cities of Uganda. Last half of the population experienced almost zero network links for welfare measures. Public spouts play a vital role in assisting a portion of about $10.6 \%$ of clans than the exclusive links, run by the NWSC.

Other than public spouts some more wellsprings include boreholes either public or private, wells either protected or unprotected, rivers, lakes, water sellers, rainwater, water tankers, flow projects, and many more. Amongst them public bores share a $34.6 \%$ of weightage, unprotected wells and springs assist $18.2 \%$ of families, and protected wells and springs help $16.8 \%$ families in the usage of water. Most of the poor population of Uganda depend on these major sources of water. Except these rivers, streams, and lakes also provide water to $10 \%$ of the poor population.

Although channeled water access has been improved for the households over certain time period. In an estimate this access has almost doubled since 2005-2006. It was the time when only $3.7 \%$ families were enjoying private connections in Uganda, although it did not influence the quantity of approach to hygienic water. Unfortunately, public spouts access did not increase over any time period. By approximate figures we can say that in 2005-2006 just $11.4 \%$ families depended on public spouts while a survey of 2012-2013 revealed that this figure even reduced to $10.8 \%$. Other than that, a survey of $2002-2003$ did not differentiate private and public connections and dependencies. 
But why these indemnity rates proceeded in absolute terms rather than relative growth rates in the uptown clientele of NSWC in bigger crowded towns of Uganda and smaller regions? As mentioned by Tsimpo and Wodon in 2017 (Tsimpo and Wodon 2019), it is partly because of increase in population. In rough stats of 2002-2003 population of Uganda as per figures of household survey was about 25.2 million. In 2012-2013 it increased to 35.3 million. But in 2007 Diallo and Wodon stated that every house is also going through decrease in number of members. As 2002-2003 survey showed average house bulk as 5.1 which then decreased to 4.8 in the survey of 2012-2013. This increased the number of families in Uganda rather than the population. By figures of 2002-03 and 2012-13 we can call it an increase from 4.9 million families to 7.1 million in a decade. It was a massive increase of 44 percent. In other words we can conclude that an average family's size reduction was held accountable for $1 / 5^{\text {th }}$ of the average growth in number of families because of population increase. Because of such circumstances, the fast increase in links from the useful organizations did not work such efficiently and showed a leisure growth in the indemnity rates.

Polls on availability of numerous water well springs are frequently presented in much clustered and much compact way. Literature do give a number of definitions of clean and safe water but the most reliable one is given by WHO UNICEF Joint Monitoring Program for Water \& Sanitation (JMP). According to which safe water is the one in which the risk factor of exterior pollution, more specifically dunk matter is minimum. And the sources for such safe and clean water involve the channeled water wellsprings either public or private, tube wells, bores, protected hand dug wells, rain water, and protected springs. While, tumbled down water wellsprings involve vulnerable wellsprings like springs, hand dug wells, water sellers, tankers, exterior surface waters and even canned waters. Another classification of safe or unsafe water, apart from improved or unimproved is drinking water-ladders.

A number of perspectives are summarized in table 3.1 below, listing all the categories available in houses of Uganda in accordance with the drinking water-ladder. Table mentions unimproved wellsprings in the end while the improved ones are classified in steps up to the channeled projects. A differentiation between channeled links and public spouts is also mentioned.

Table I Categorization of water sources by JMP water-hierarchy

\begin{tabular}{|c|c|c|c|c|}
\hline Questionary & 2002/03 Survey & 2005/06 Survey & 2009/10 Survey & 2012/13 Survey \\
\hline $\begin{array}{l}\text { Channeled } \\
\text { project }\end{array}$ & $\begin{array}{l}\text { Spouts/ } \\
\text { water }\end{array}$ & Personal links & Private connection & $\begin{array}{l}\text { Channeled water in the } \\
\text { plots }\end{array}$ \\
\hline
\end{tabular}




\begin{tabular}{|c|c|c|c|c|}
\hline & & & & $\begin{array}{l}\text { Channeled water in the } \\
\text { houses }\end{array}$ \\
\hline & Gravity flow projects & Common spouts & General Spouts & General Spouts \\
\hline & & Gravity flow projects & Gravity flow projects & Gravity flow scheme \\
\hline Water hole & Waterholes & Waterholes & & $\begin{array}{l}\text { Waterhole in houses } \\
\text { Common waterhole }\end{array}$ \\
\hline More & Secured well/spring & well/spring & well/spring & Protected well/spring \\
\hline $\begin{array}{l}\text { Ameliorated } \\
\text { sources }\end{array}$ & Precipitations & Rainwater & Rainwater & Rainwater \\
\hline \multirow[t]{3}{*}{$\begin{array}{l}\text { Unimproved } \\
\text { sources }\end{array}$} & $\begin{array}{l}\text { Unbolted water } \\
\text { wellsprings }\end{array}$ & $\begin{array}{l}\text { River/stream/lake/pond } \\
\text { Unprotected well/spring }\end{array}$ & $\begin{array}{l}\text { River/stream/lake/pond } \\
\text { Sellers/ Tank Lorry }\end{array}$ & $\begin{array}{l}\text { Unprotected well/ } \\
\text { spring }\end{array}$ \\
\hline & $\begin{array}{c}\text { Water } \\
\text { sellers }\end{array}$ & Vendor/tanker truck & & $\begin{array}{l}\text { River/stream/lake } \\
\text { Sellers }\end{array}$ \\
\hline & & & & Tank lorry \\
\hline Further & Further & Further & Further & Canned water Further \\
\hline
\end{tabular}

Unit: Percentage of population affected

Another table 3.2 shows the stats of approachability to the improved and unimproved water wellsprings. A number of subcategories of improved wellsprings as mentioned by the water ladder are also mentioned. Undoubtedly the approach to such ameliorated wellsprings has increased with the passage of time span but quite steadily. As per survey reports of 2002-2003 67.2\% families had the access to improved sources while in 2012-2013 it increased to $72.4 \%$ only. In the poll named as Demographic and Health survey (2011), the ratio of houses enjoying the access to improved sources was approximated to 70 percent. In simple words, the progression reports for approachability to safe and clean water seems to be quite lean over a decade. Figure 3.1 is elaborating the visual trends in approachability by the area over certain time period.

Data about the distance of water wellsprings from the houses is also noted. The time which is needed to travel just in order to fetch water daily is much and is noted in certain surveys. This time as by survey of 2012-2013 is substantially about 0.8 kilometers. Unfortunately in some regions this distance is even longer that is about five kilometers or even longer. So if converted to time on average an hour is utilized just in fetching of water for a house in Uganda including the time surged for waiting in the lines. Considering some remote areas this time extends to two hours as well because of some difficult landscape. Three hours is also common for some people 
to wait for the water at the wellsprings. As per expectations, water wellsprings are tracked down nearer to the dwells and so it takes lesser time in Kampala as compared to other to cities. These estimates are made according to the Demographic and Health Survey 2011. 


\section{Table II Ameliorated Water Wellsprings \& Imbibing Water-Hierarchy}

\begin{tabular}{|c|c|c|c|c|c|c|c|c|c|c|c|c|c|}
\hline & \multicolumn{3}{|c|}{ Locality } & \multicolumn{4}{|c|}{ Domain } & \multicolumn{5}{|c|}{ Wellbeing quintile } & \multirow[b]{2}{*}{ Sum } \\
\hline & Kampala & $\begin{array}{l}\text { Other } \\
\text { Towny }\end{array}$ & Pastoral & Interior & \multicolumn{2}{|c|}{ Eastward Arctic } & Westward & 1 & 2 & 3 & 4 & 5 & \\
\hline \multicolumn{14}{|c|}{$2005 / 06$} \\
\hline Ameliorated & 90.8 & 84.0 & 64.0 & 63.4 & 81.9 & 75.4 & 55.3 & 69.6 & 67.9 & 63.0 & 67.5 & 71.4 & 68.0 \\
\hline Waterhole & 0.7 & 21.8 & 33.8 & 16.5 & 50.0 & 51.4 & 12.0 & 44.1 & 35.8 & 30.0 & 26.8 & 19.2 & 30.0 \\
\hline ameliorated & d 21.0 & 15.2 & 22.5 & 22.1 & 21.2 & 16.0 & 26.1 & 20.0 & 23.8 & 22.2 & 23.8 & 18.9 & 21.7 \\
\hline \multicolumn{14}{|l|}{ Wellsprings } \\
\hline Worn out wellsprings & 8.9 & 15.7 & 35.6 & 36.2 & 18.1 & 24.4 & 43.9 & 30.1 & 32.0 & 36.7 & 31.8 & 28.1 & 31.6 \\
\hline Other & 0.4 & 0.3 & 0.4 & 0.4 & 0.1 & 0.2 & 0.9 & 0.3 & 0.1 & 0.3 & 0.7 & 0.5 & 0.4 \\
\hline Ameliorated wellsprings & 92.2 & 86.3 & 62.8 & 64.3 & 71.9 & 70.8 & 63.4 & 61.2 & 61.7 & 66.6 & 67.2 & 75.2 & 67.2 \\
\hline Channeled projects & 78.7 & 44.6 & 8.8 & 27.3 & 10.6 & 4.5 & 21.0 & 5.5 & 8.4 & 10.9 & 17.1 & 35.3 & 17.3 \\
\hline Waterholes & 0.0 & 22.8 & 31.5 & 20.6 & 44.3 & 37.9 & 14.9 & 34.7 & 29.1 & 31.8 & 27.2 & 22.7 & 28.4 \\
\hline $\begin{array}{l}\text { Other Ameliorated } \\
\text { wellsprings }\end{array}$ & d 13.5 & 19.0 & 22.5 & 16.5 & 17.0 & 28.4 & 27.5 & 21.0 & 24.3 & 23.9 & 22.9 & 17.2 & 21.5 \\
\hline Worn out wellsprings & 7.2 & 13.3 & 36.8 & 35.1 & 27.7 & 28.8 & 36.4 & 38.4 & 37.9 & 33.0 & 32.7 & 24.1 & 32.4 \\
\hline Further & 0.6 & 0.4 & 0.4 & 0.6 & 0.4 & 0.4 & 0.3 & 0.4 & 0.4 & 0.4 & 0.2 & 0.7 & 0.4 \\
\hline Sum & 100.0 & 100.0 & 100.0 & 100.0 & 100.0 & 100.0 & 100.0 & 100.0 & 100.0 & 100.0 & 100.0 & 100.0 & 100.0 \\
\hline
\end{tabular}

Unit: Percentage of population affected 
a. 2002/03

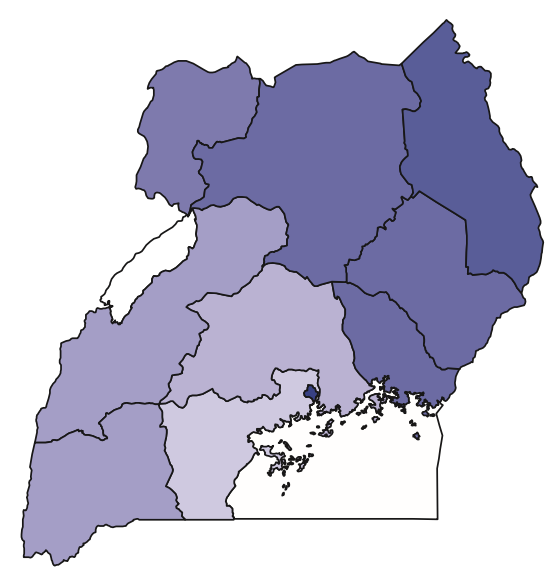

c. $2009 / 10$

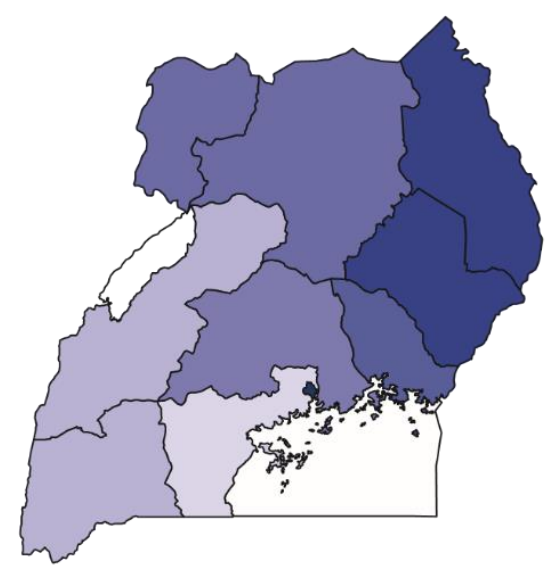

$\square 95-100 \% \quad \square 90-95 \% \quad \square 85-90 \% \square 80-85 \% \quad \square 75-80 \%$

$\square 70-75 \% \quad \square 65-70 \% \quad \square 60-65 \% \square 55-60 \% \quad \square 50-55 \% \quad \square$ No data b. $2005 / 06$

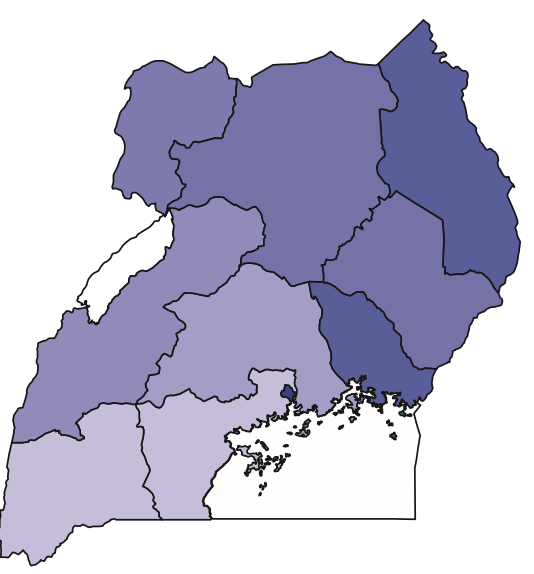

d. $2012 / 13$

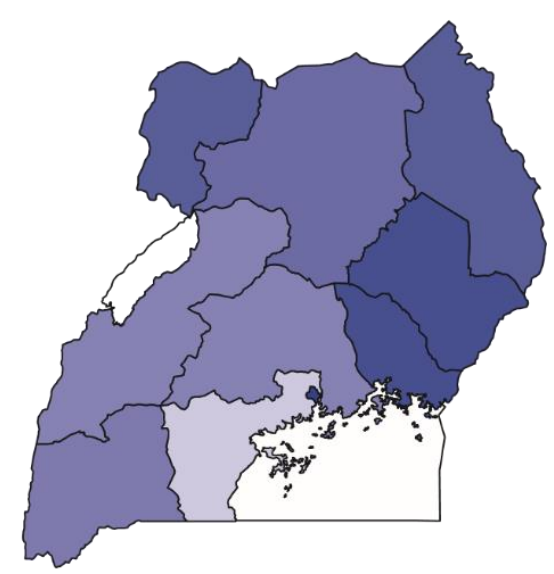

Figure V Houses using Improved Water Wellsprings 2002-13

\section{- 2020 Progress Update}

As mentioned above, Uganda is facing serious water crisis, and national, local governments alongside NGOs, UN, WHO and local communities are collectively working to solve these issues. With the help of these agents they are progressing.

As recorded in 2000, about 14 percent of Ugandans were dependent on exterior water sources.

But according to the recent facts and figures this percentage has cut to almost half. 


\subsubsection{Limitations for Access to Safe Water}

These surveys and the field works still show a large number of limitations. Survey data represents that tariff is one of the factors in not have approach to safe and clean water for some families specifically in Kampala. Many areas have the limitation of distance to clean water. Although the group leaders assure that water for the people who buy it is much costly, and recommending them to prioritize water over necessities. These fiscal restrictions appear to be a widespread study in the wealthy regions of Uganda and in Kampala. The areas where people are well off but still they need to pay for the most basic necessity that is water. Comparing these circumstances of the communities with the rural areas, where water is unprotected but fortunately it is without any cost. Certain rural areas where certain communities do not put in area methodologies that can make water protected and safe, pay for it.

A quick quantifiable survey of certain responses as given by the members of the focus categories on the crisis they are going through in terms of approachability of safe and clean water shows that worries of sufficiency, modest costs, alongside distance and operational water architectures, influence in cities. Rural areas are facing crisis with respect to costs they pay for buying water, in concurrence with the agitation about the sufficiency, performance, and standard of the water wellsprings, alongside the distance from homes to the wellsprings.

Table III Community Marks on Rates and Reasonability of Water 2012-2013

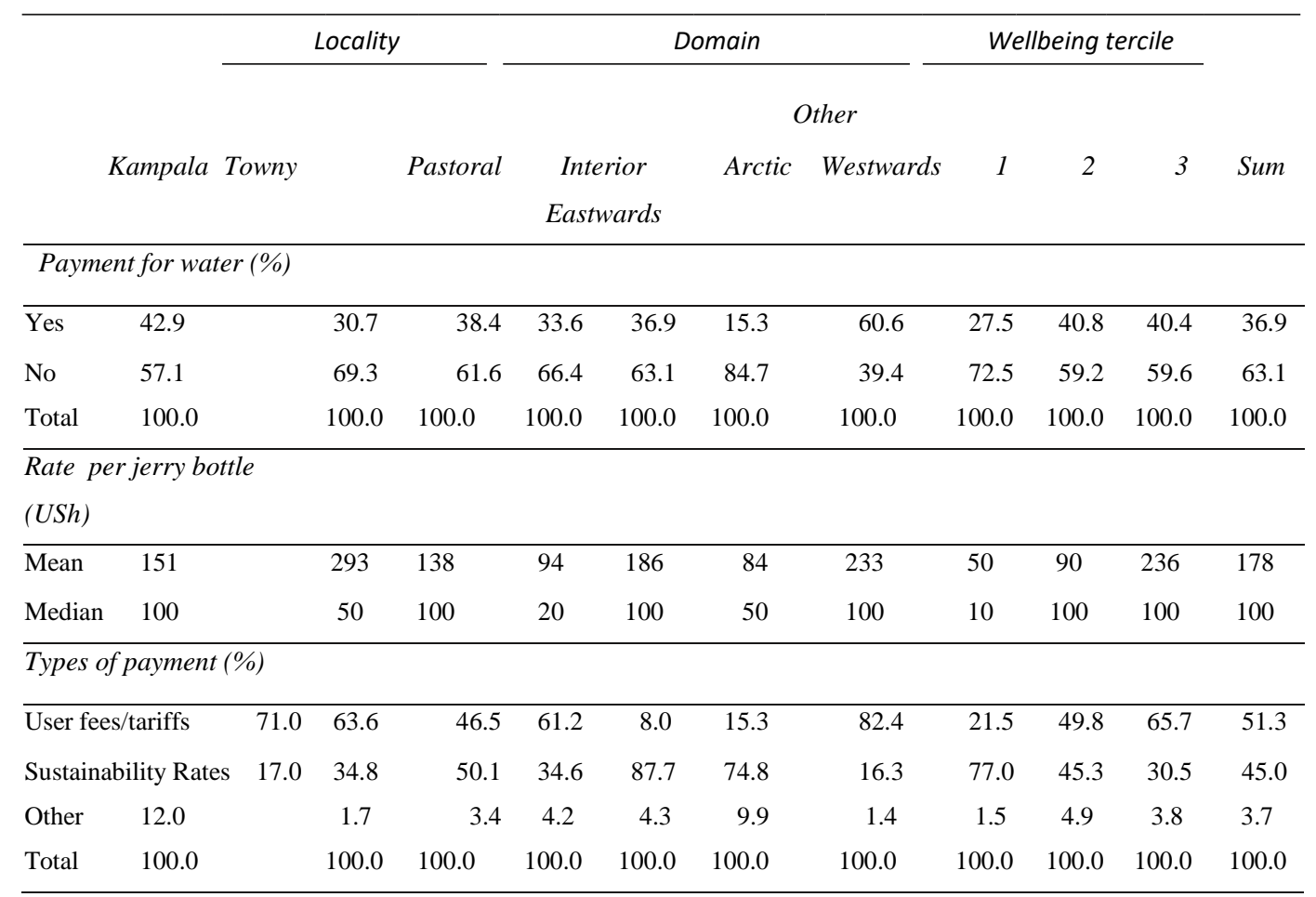




\begin{tabular}{|c|c|c|c|c|c|c|c|c|c|c|c|}
\hline \multicolumn{12}{|c|}{ Rates for Houses (USh) } \\
\hline \multicolumn{2}{|c|}{ Mean (monthly) } & 16,513 & 9,489 & 17,703 & 1,845 & 3,223 & 18,342 & 5,475 & 9,521 & 17,741 & 12,451 \\
\hline \multicolumn{12}{|c|}{34,897} \\
\hline \multicolumn{2}{|c|}{ Median (monthly) } & 15,000 & 2,000 & 10,000 & 500 & 1,000 & 18,000 & 1,000 & 3,000 & 15,000 & 6,000 \\
\hline \multicolumn{12}{|c|}{30,000} \\
\hline \multicolumn{12}{|c|}{ Reasonability of prices } \\
\hline \multicolumn{12}{|l|}{$(\%)$} \\
\hline Yes & 20.7 & 24.8 & 32.3 & 29.7 & 41.1 & 35.1 & 21.6 & 37.4 & 32.6 & 25.3 & 30.2 \\
\hline No & 79.3 & 75.2 & 67.7 & 70.3 & 58.9 & 65.0 & 78.5 & 62.6 & 67.4 & 74.7 & 69.8 \\
\hline Sum & 100.0 & 100.0 & 100.0 & 100.0 & 100.0 & 100.0 & 100.0 & 100.0 & 100.0 & 100.0 & 100.0 \\
\hline
\end{tabular}

Unit: Percentage of population affected

\subsection{SANITATION}

Sanitation is not something just related to toilets, but it also involves all sort of prerequisites, actions, and even the utilities that ward off those diseases which happened because of the exposure to human excretions. Hygiene is known as the actions and conducts that can help in the improvements to keep clean and as a result enjoying sound health.

Around the globe about one out of every three people do not keep track of uncontaminated toilets in their places. As a matter of fact, we all know that cleanliness and sanitation are crucial needs for safe and sound health, economic prosperity, one's own security and self-respect, more importantly for females. If you outlay for the cause of sanitation it can clearly reduce the expenditure for health care services. Hence, fertility improves as you can get much time for work and education purposes. Unfortunately, chiliads of children die daily around the globe because of diarrheal diseases that are the reason of insufficient sanitation. Even today in 2021 when world is progressing digitally, more number of people have approach to mobiles rather than the toilets, the basic necessity of life. And this inability has cost about 220 billion dollars to the worldwide wealth in 2015 .

\subsubsection{Sanitation and USAID}

USAID is an organization that assists the underdeveloped countries to cope up with the open excretions, and upgrade their hygienic and sanitation resources. Moreover, it helps them to progress forward towards safe management, and creating better hygienic conducts that could last long. Sanitation goals of USAID involves: 
- To reduce the tally of people who excrete in open areas

- To increase the amount of people who could have access to fundamental sanitation prerequisites

- To ameliorate the low-cost and accessibility of sanitary wares and overhauls

- To ameliorate the effective usage of the human and animal dunks by collecting, transporting, and treating it externally

- To ameliorate the capability to educate the people in order to manage the cleanliness and hygienic resources in the educational and health institutes

- To ameliorate amount of people having safe, and hygienic facilities

- To ease the process of washing hands using soaps in need

- To ameliorate the gauge of secure administration of clean water in houses

Completing the worldwide cleanliness and public health gap are the basic aims of United States Government Global Water Strategy and USAID's water and progression plan.In assistance to the water strategy, USAID is aiming to help eight million people in having access to sanitary facilities by 2022. To sum up, the USAID's work is promoting the organizations globally are helping to approach the better water and cleanliness steps, and promoting the fundamental hygiene conducts.

\subsubsection{Sanitation and Uganda}

Sanitation is an emerging problem. Considering some factors of poor sanitation like, health issues (diarrhea), effect on fertility, and self-respect. For now even think of it that about 2.5 billion people are anticipated to move towards urban areas in the coming 30 years. It is considered that these problems can intensify magnificently if not took in account. Uganda is one such country in particular where these problems are rising extremely fast. One of its city Kampala's $85-90 \%$ locality is severely affected by it. Only $10-15 \%$ is enjoying formal links of sewerage system. An average of 30-40\% of the citizens of Kampala are living in certain formal houses. Rest are living in informal ones. And in upcoming urbanization years this population is going to face too much. Currently enrolling Uganda's two-third of the urban population Kampala is one of the primary cities of the country. It is expected that the population growth of the country would severely increase by $15 \%$. Definitely the pressure on sanitary things would drastically increase and what is more concerning that it is expected to miss the target of the year. Hence, touching 7 million mark of the population not enjoying sanitation facilities. 


\section{ACCESS TO SANITATION IS LOW}

3 OUT OF 10

UGANDAN HOUSEHOLDS DO NOT HAVE A LATRINE

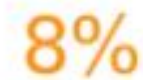

OF MOTHERS WITH CHILDREN UNDER 5 HAVE SOAP AND

WATER READILY AVAILABLE FOR HAND WASHING

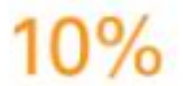

OF UGANDANS PRACTISE OPEN DEFECATION

Figure VI Analysis of Ugandan Children 2015

\subsubsection{Drifts in Approach to Sanitary Facilities}

Focusing on the toilet amenities, dunk dumping, and washing hands this topic is going to discuss access to basic sanitary facilities, according to the previous four survey named as Uganda's National Household Surveys. Certain comparisons between all four surveys and one or two surveys is also provided because of some differences in all studies. Table 3.4 represents the data collected on kinds of toilets used by the houses in accordance with the survey of 20122013. It shows that only 7.3\% houses of Uganda are having flush toilets or VIP latrine. And interestingly, these amenities are available in the areas enjoying best social quintile rather than the poor as areas like Kampala are overcrowded.

These kind of bathrooms are almost unavailable in the last four quintiles. Moreover the remaining quintiles even show the deviations. Many of the houses still depend on the pit toilets, either exposed or engulfed, with or without wodge. Size is again not necessary. The deviation is in terms that one out of four houses amongst the bottom quintiles do not have the approachability to latrines and hence, use bushes, containers, pitchers or any other modes. And this bottom most quintile has the highest ratio of usage of such modes.

In general, in the last decade comparing the first house study (2002-2003) and the last study (2012-2013), considering the inconsistent questions, a lean betterment have been seen in the 
kinds of toilets used. Figure 3.3 proves it through visuals notifying the proportion of houses with no toilets in the decade. An increase has been seen locally in some areas, but 2012-2013 mentioned a percentage of $9.7 \%$ locally, while in $2002-2003$ it was seen to be $13.3 \%$. Sadly, studies do not show complete drift over this decade as mentioned by JMP.

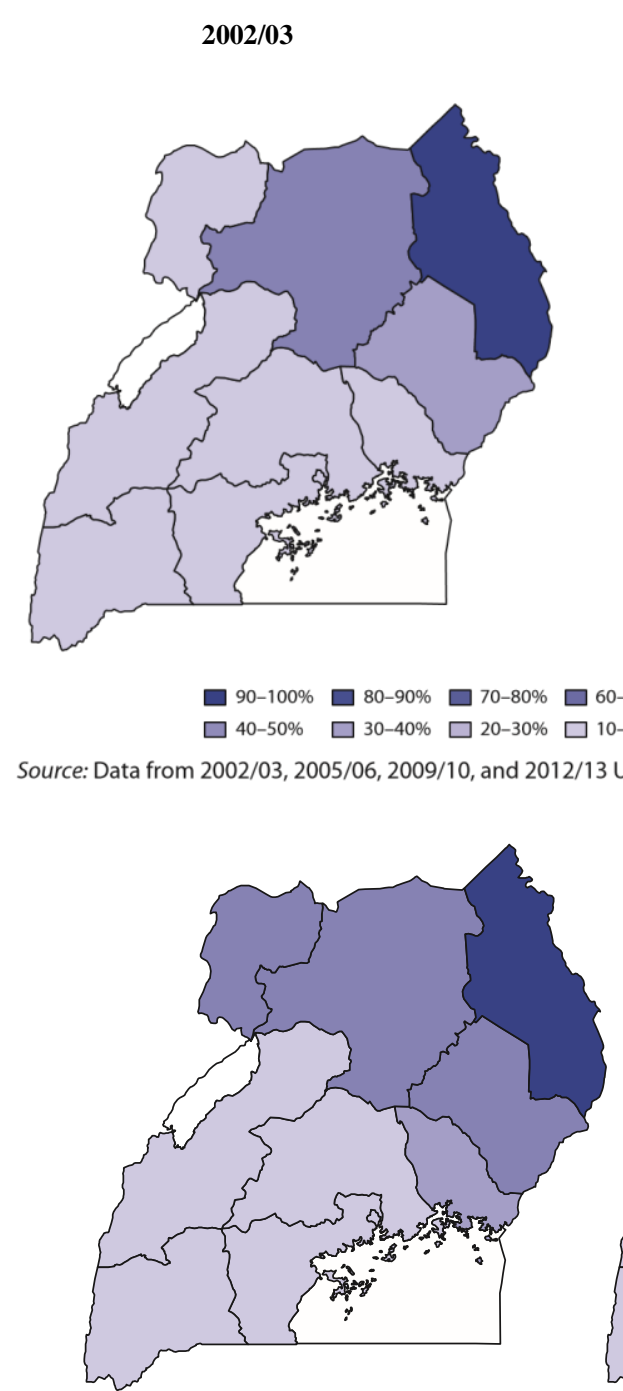

2002/03

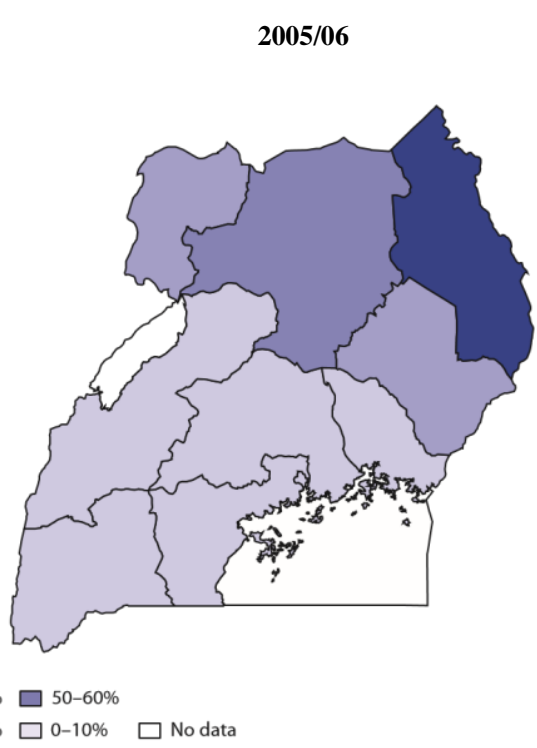

$\square$ Nodata

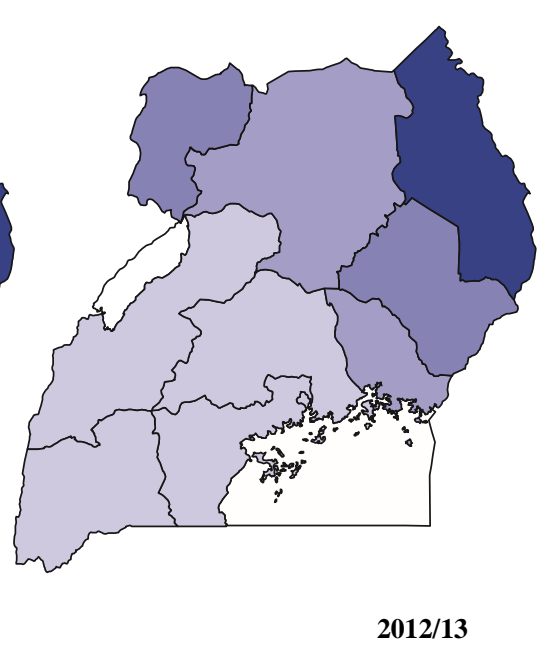

Figure VII Proportion of Houses without Toilets 2002-2013

Table 3.4 lists another category of toilets used namely Eco-San. These latrines are the ones where urine and feces can be separated and recycled. As mentioned in the list, not even $1 \%$ population depends on these latrines in 2012-2013, irrespective of the efforts made by the NGOs. A cultural facet is also involved in this part. 


\section{Table IV Types of Toilets Used by Ugandans}

\begin{tabular}{|c|c|c|c|c|c|c|c|c|c|c|c|c|c|}
\hline & \multicolumn{3}{|c|}{ Locality } & \multicolumn{4}{|c|}{ Domain } & \multicolumn{5}{|c|}{ Wellbeing quintile } & \multirow[b]{2}{*}{ Sum } \\
\hline & Kampala & $\begin{array}{l}\text { Other } \\
\text { Towny }\end{array}$ & Pastoral & Interior & \multicolumn{2}{|c|}{ Eastward Arctic } & Westward & Q1 & Q2 & Q3 & Q4 & Q5 & \\
\hline \multicolumn{14}{|c|}{$2012 / 13$} \\
\hline Dislodge latrines & 14.0 & 3.0 & 0.2 & 3.3 & 0.6 & 0.4 & 1.2 & 0.0 & 0.0 & 0.2 & 1.0 & 4.5 & 1.5 \\
\hline VIP toilets & 22.4 & 12.6 & 2.6 & 12.6 & 2.7 & 1.7 & 4.2 & 0.7 & 1.7 & 2.7 & 5.1 & 13.7 & 5.8 \\
\hline Enclosed holes, with block & 32.8 & 32.8 & 13.5 & 29.5 & 19.8 & 8.2 & 12.6 & 9.0 & 11.0 & 14.8 & 20.0 & 30.3 & 18.6 \\
\hline Enclosed holes w/o block & 28.2 & 31.8 & 48.2 & 24.9 & 49.4 & 40.6 & 63.4 & 41.7 & 51.8 & 47.7 & 47.7 & 34.0 & 43.6 \\
\hline Open holes, with blocks & 1.7 & 5.8 & 4.6 & 7.5 & 5.5 & 2.4 & 2.5 & 3.7 & 4.7 & 5.9 & 4.6 & 4.6 & 4.7 \\
\hline Open holes, w/o blocks & 0.5 & 8.1 & 18.2 & 17.1 & 13.2 & 15.9 & 14.0 & 18.3 & 18.9 & 17.7 & 15.1 & 9.2 & 15.1 \\
\hline $\begin{array}{l}\text { Ecological Sanitation (compost } \\
\text { latrines) }\end{array}$ & 0.0 & 1.0 & 0.9 & 0.4 & 0.7 & 2.1 & 0.7 & 1.6 & 1.0 & 0.5 & 1.2 & 0.5 & 0.9 \\
\hline $\begin{array}{l}\text { No prerequisites/shrubs/sacks/and so } \\
\text { on }\end{array}$ & 0.2 & 5.0 & 11.8 & 4.8 & 8.2 & 28.7 & 1.5 & 24.9 & 10.9 & 10.5 & 5.3 & 3.2 & 9.7 \\
\hline Other & 0.2 & 0.0 & 0.0 & 0.1 & 0.0 & 0.1 & 0.0 & 0.0 & 0.1 & 0.1 & 0.1 & 0.0 & 0.0 \\
\hline Total & 100.0 & 100.0 & 100.0 & 100.0 & 100.0 & 100.0 & 100.0 & 100.0 & 100.0 & 100.0 & 100.0 & 100.0 & 100.0 \\
\hline \multicolumn{14}{|c|}{$2009 / 10$} \\
\hline Enclosed holes, personal & 8.0 & 19.1 & 41.6 & 30.7 & 34.3 & 26.7 & 54.9 & 34.9 & 42.7 & 39.5 & 39.1 & 29.9 & 36.6 \\
\hline Enclosed holes, public & 63.5 & 58.2 & 26.6 & 38.7 & 31.1 & 36.8 & 24.2 & 19.8 & 25.7 & 30.4 & 37.4 & 42.9 & 32.9 \\
\hline VIP personal toilets & 2.0 & 1.6 & 1.2 & 2.8 & 1.0 & 0.4 & 0.3 & 0.7 & 0.2 & 0.4 & 1.2 & 2.9 & 1.3 \\
\hline VIP public toilets & 7.9 & 6.2 & 1.4 & 5.3 & 0.9 & 1.5 & 0.9 & 0.2 & 0.9 & 0.8 & 1.5 & 6.2 & 2.4 \\
\hline
\end{tabular}




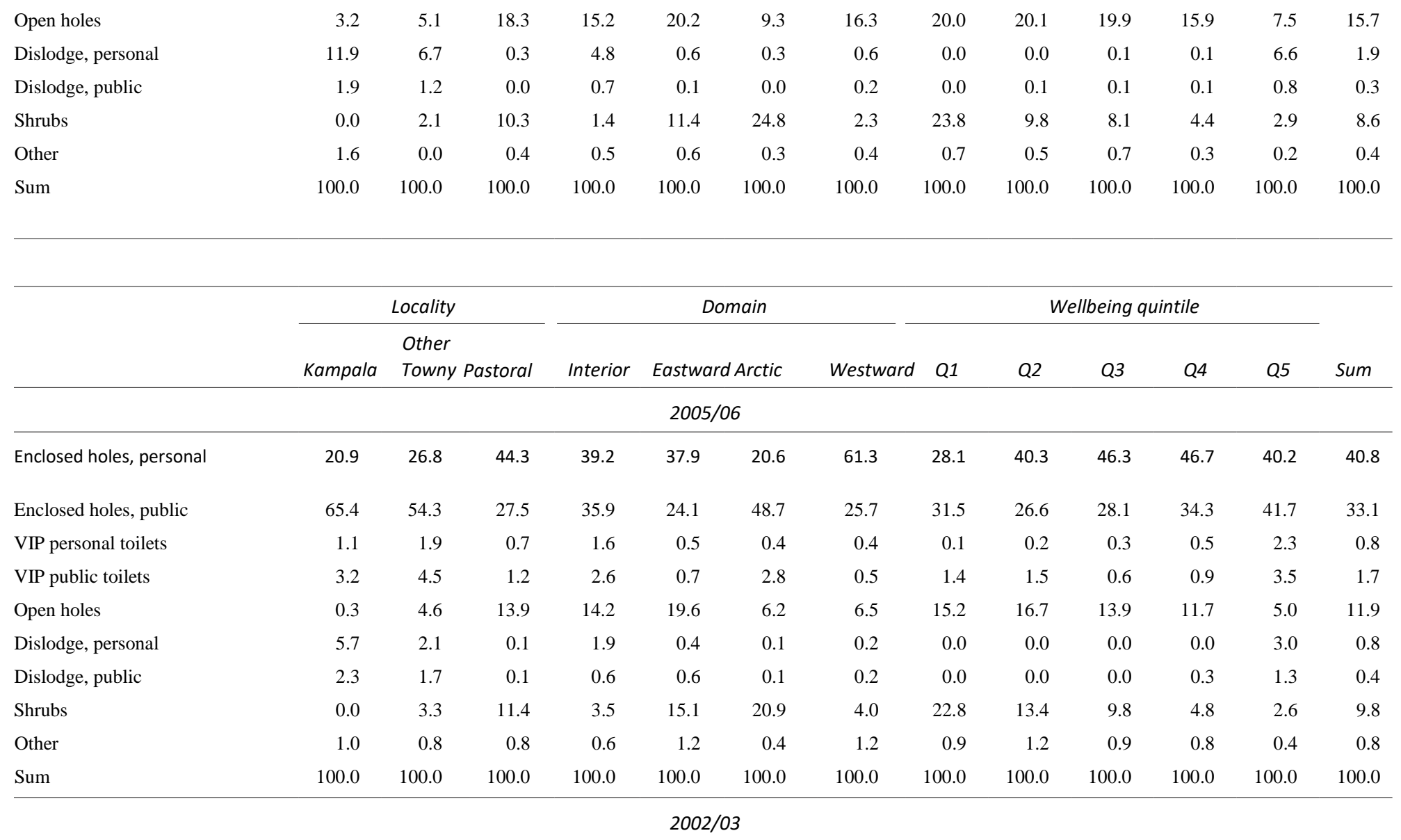




\begin{tabular}{|c|c|c|c|c|c|c|c|c|c|c|c|c|c|}
\hline Enclosed holes, personal & 19.8 & 26.2 & 48.5 & 42.4 & 39.7 & 20.2 & 69.4 & 32.3 & 46.2 & 50.8 & 50.3 & 41.0 & 44.2 \\
\hline Enclosed holes, public & 65.6 & 54.1 & 22.1 & 33.5 & 23.9 & 36.8 & 19.9 & 19.3 & 23.3 & 22.9 & 28.8 & 40.9 & 28.3 \\
\hline VIP personal toilets & 0.8 & 1.7 & 1.1 & 2.0 & 0.7 & 0.7 & 0.9 & 0.1 & 0.8 & 0.9 & 1.0 & 2.2 & 1.1 \\
\hline VIP public toilets & 6.8 & 3.9 & 0.5 & 2.8 & 0.7 & 0.5 & 0.5 & 0.2 & 0.1 & 0.7 & 1.7 & 3.0 & 1.3 \\
\hline Open holes & 0.0 & 5.2 & 12.1 & 12.4 & 15.6 & 7.5 & 5.2 & 15.4 & 13.2 & 11.8 & 10.3 & 5.2 & 10.6 \\
\hline Dislodge, personal & 5.2 & 3.7 & 0.1 & 1.5 & 0.6 & 0.2 & 0.5 & 0.0 & 0.1 & 0.0 & 0.1 & 2.9 & 0.8 \\
\hline Dislodge, public & 1.5 & 2.6 & 0.0 & 0.4 & 0.5 & 0.2 & 0.3 & 0.0 & 0.0 & 0.1 & 0.3 & 1.1 & 0.4 \\
\hline Shrubs & 0.0 & 2.3 & 15.0 & 4.2 & 17.1 & 33.5 & 3.4 & 31.6 & 16.2 & 12.1 & 7.0 & 3.3 & 12.7 \\
\hline Other & 0.4 & 0.4 & 0.6 & 0.7 & 1.2 & 0.3 & 0.0 & 1.0 & 0.3 & 0.7 & 0.6 & 0.5 & 0.6 \\
\hline Sum & 100.0 & 100.0 & 100.0 & 100.0 & 100.0 & 100.0 & 100.0 & 100.0 & 100.0 & 100.0 & 100.0 & 100.0 & 100.0 \\
\hline
\end{tabular}


Unit: Percentage of population affected

The data in figure 3.4 shows that just $14 \%$ houses have an approach to better sanitary facilities. If we divide the worn out amenities between public and upgraded, and public and worn out, the ratio of upgraded public amenities is about $17.3 \%$. These figures openly depict that a large number of families cannot have an access to sufficient sanitary resources and if by chance they get an access to the resources they are public utilized by many families. Map below shows the visuals of accessibility to upgraded washrooms by the Kampala state.

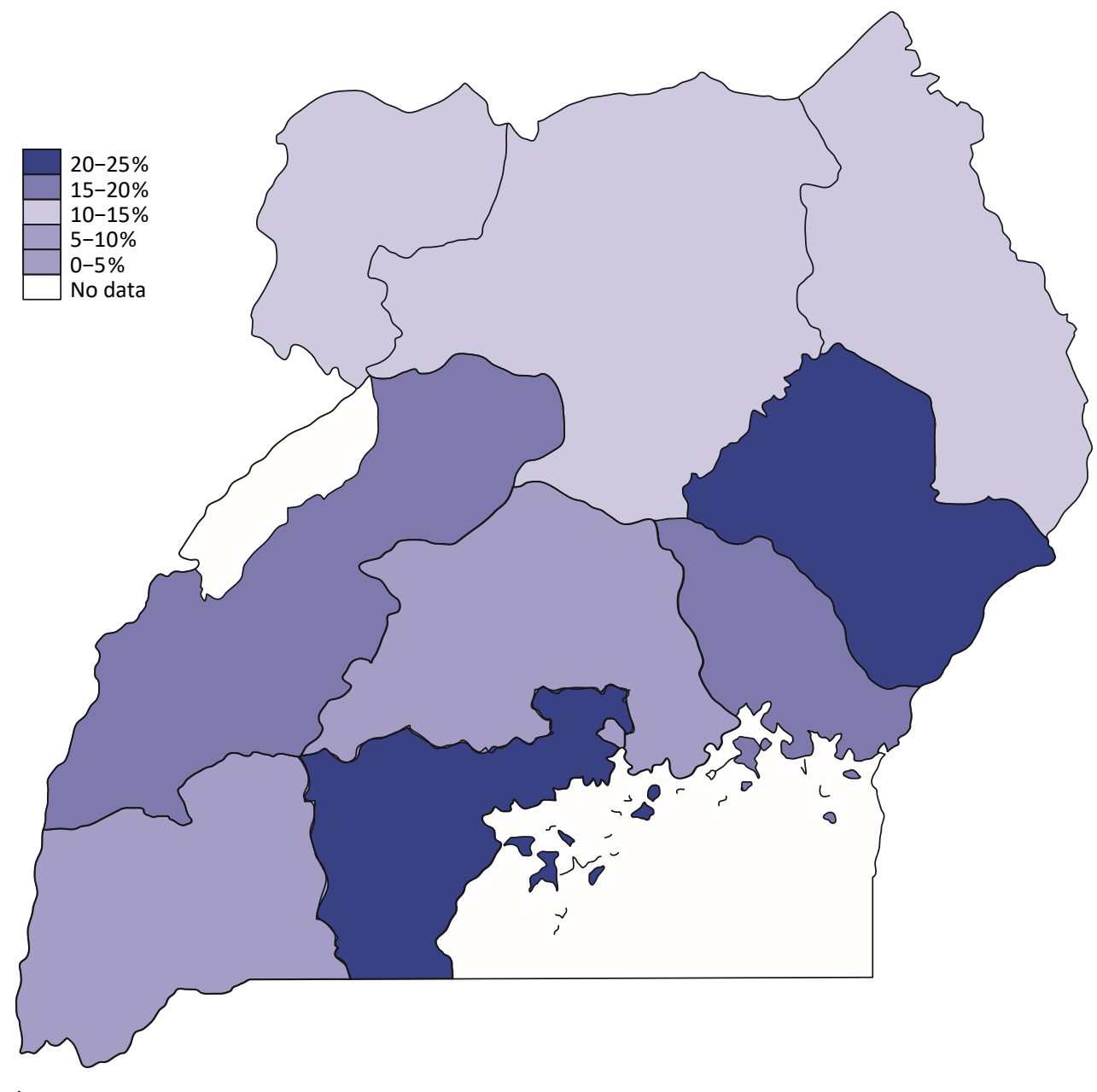

Figure VIII Ratio of Houses Using an Improved Toilets, 2012/13

Now, taking a look at table 3.5 below, indicating data related to the access to the resources of washing hands in houses. About $85 \%$ of the families cannot wash hands because of the inaccessibility to soap or water. And in case if some households have water soap is unavailable. 
Table V Proportion of Houses without Hand Washing Facilities

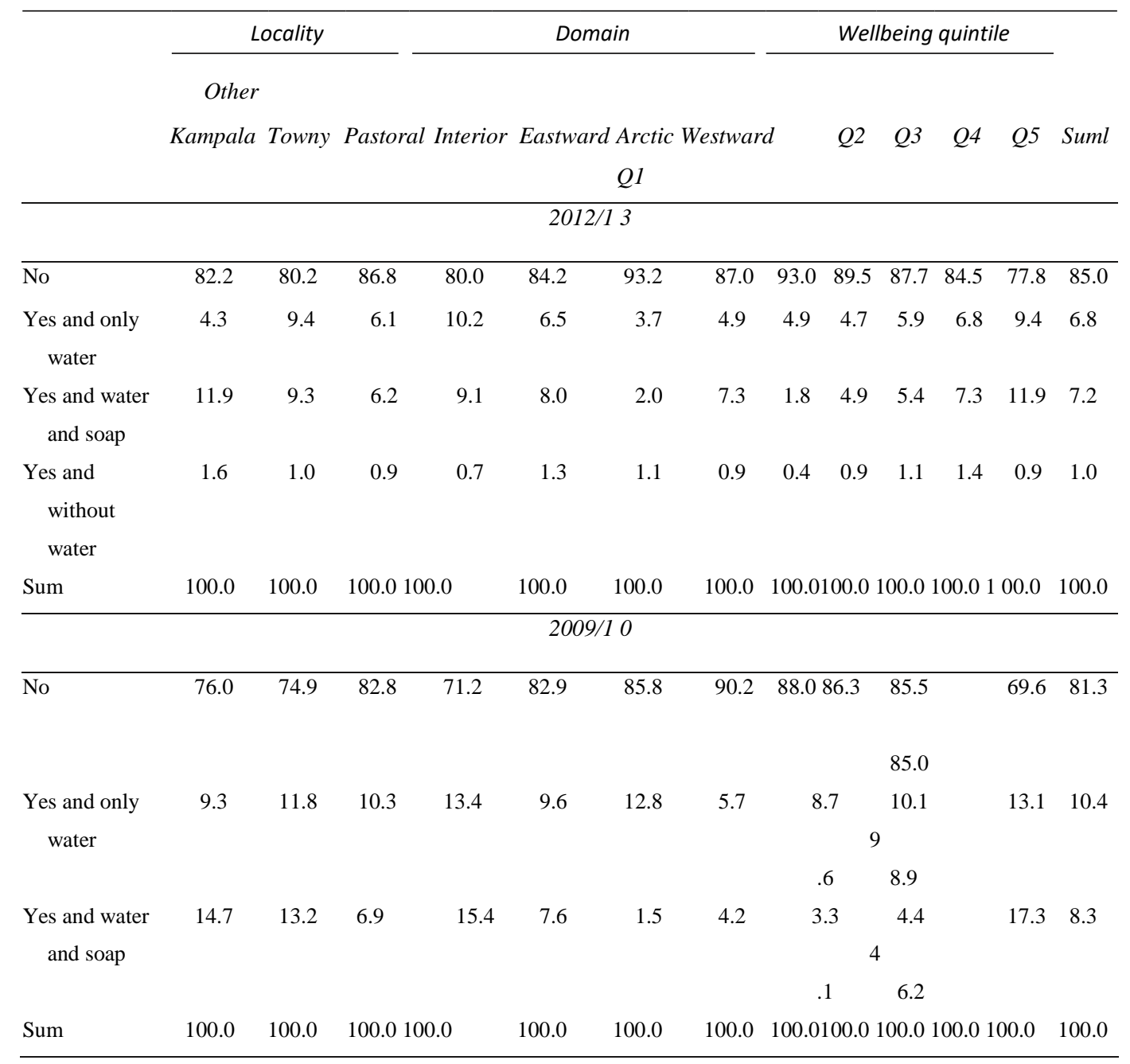

Unit: Percentage of population affected

Finally, exposing some data about the most common means to dispose solid waste materials by the Ugandans. About 43.4\% houses use open areas like gardens, 31.8\% Kampala's population throw it out in the holes, and $11.2 \%$ population pile it up in open areas. A large population of Kampala is also dependent on the waste sellers to dispose solid waste. Burning the dirt is another method used by $1 \%$ of the population. Skip bins is getting more popular over certain time period. Temporary latrines are used by $35.3 \%$ people while $25.5 \%$ people re not exposed to even them as well. About $40 \%$ of population use exterior bathrooms either with drainage source or without the drainage source. Inside baths are utilized by only wealthy population of Kampala, few and fewer. 
Table VI Most Common Means to Dispose Solid Waste

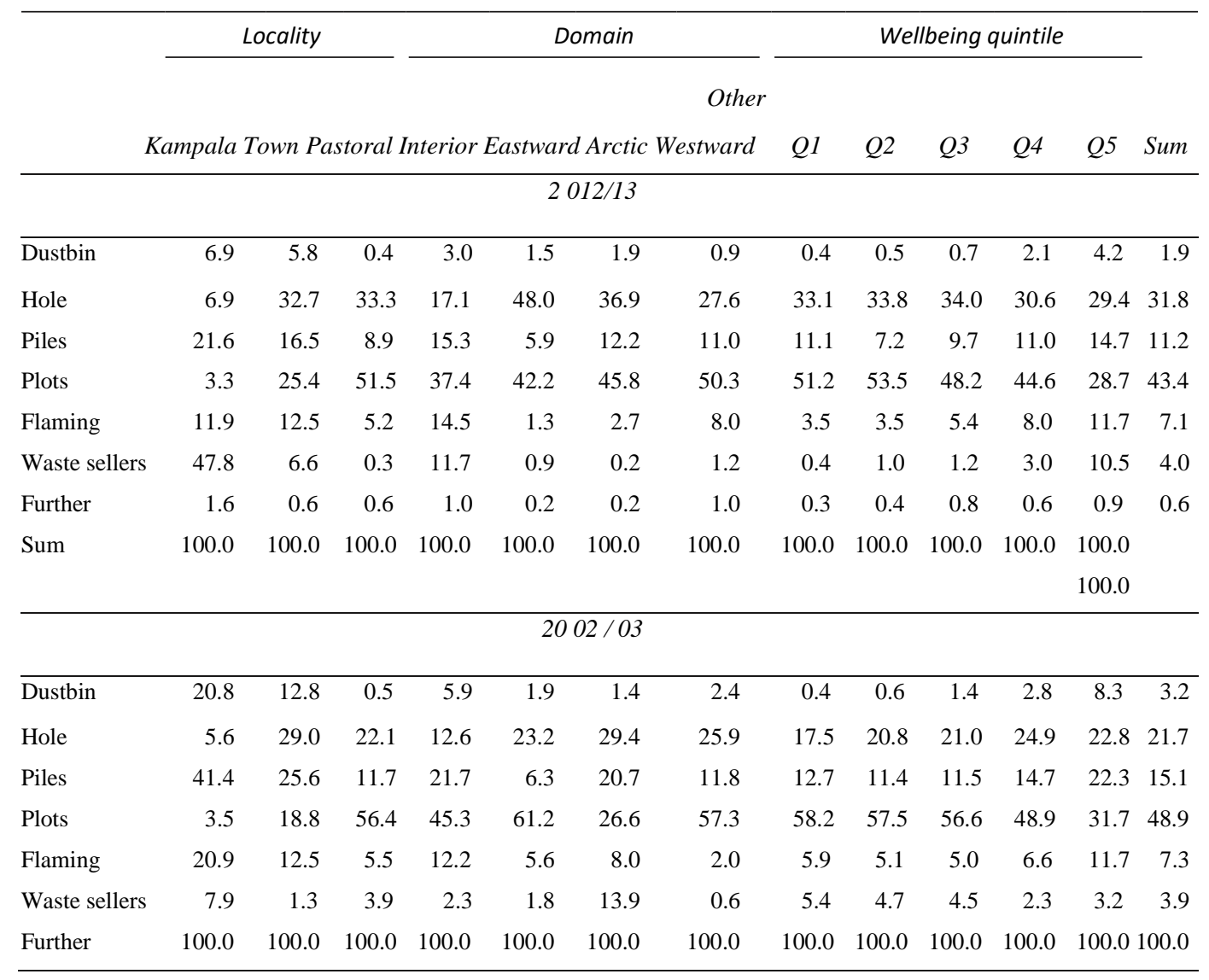

Unit: Percentage of population affected

\subsubsection{Limitations to Access to Sanitation}

A survey of Uganda National Panel Survey of 2010-2011's community module shows some discernments. In the group block of that survey, the causes for such less number of latrines in the groups was explained. The reasons involve less salary, pessimistic conducts, and irregular terrain, alongside pathetic soil used to construct toilets, incomprehension, and homelessness.

As the table below shows, group leaders considered that incomprehension was the major cause that is about $38.4 \%$ population was ignored. Pessimistic conducts towards hygiene made about $18.1 \%$ population deprived of latrines. Lesser salaries was the third most popular reason making $15.2 \%$ population deprived of latrines. $6-7 \%$ population was affected because of pathetic terrain, soil kind, or deficiency of land.

Table VII Major Reason for Incomplete Latrines 2010-2011

$\frac{\text { Locality }}{\text { Other }} \frac{\text { Domain }}{\text { Wellbeing tercile }}$




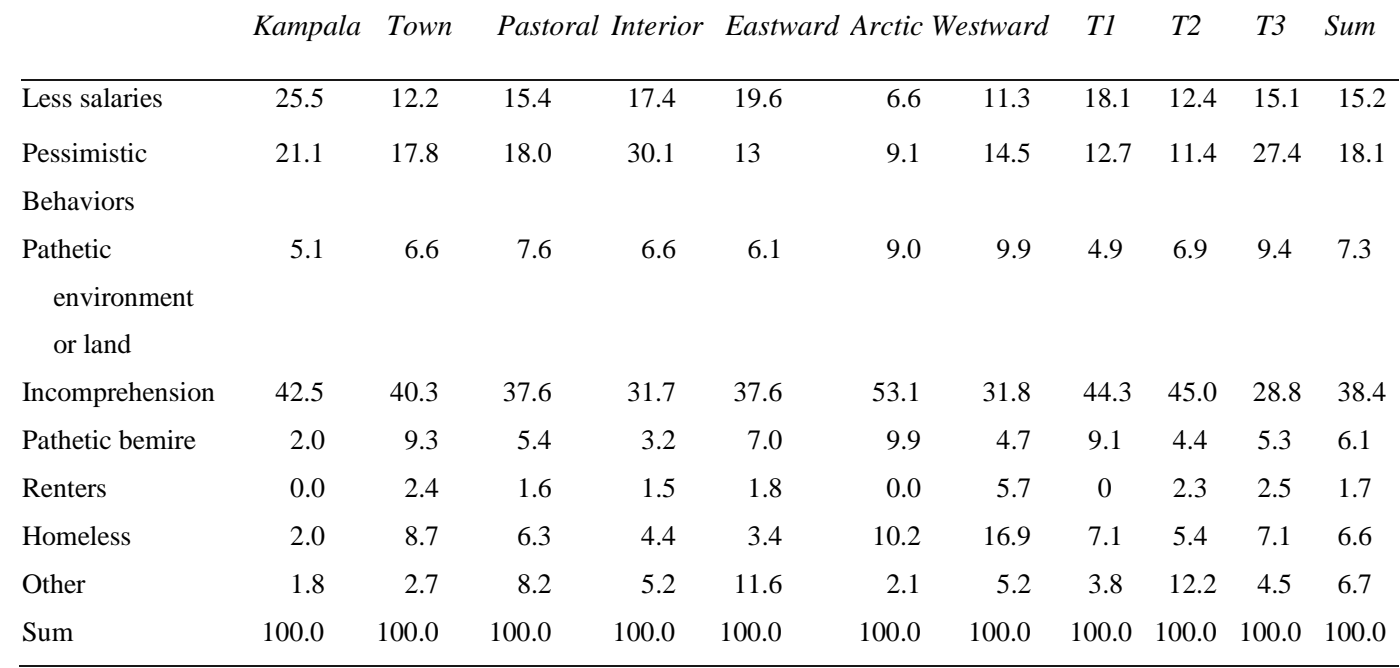

Unit: Percentage of population affected

Hence, the defendants wished for more privacy in the matter of toilets. The need for water and soap has been a definite requirement for public latrines. Even many general latrines were not completely operational.

\subsection{SDGs}

Sustainable Development Goals are the international aims adjusted by UNGA in the year 2015 . These objectives are a bank of seventeen different but interconnected worldwide aims that are formulated geared towards making a draft and gain finer stable hereafter for every single body. They are considered to be gained by 2030 .

Almost every nation of the world has tackled to ameliorate the world and lifestyle of every single citizen of it by 2030. They assured to follow the aimed seventeen transformational aims. A few major goals of them are eradicating destitution, providing improved health services, and providing equal rights to women. These aims must be followed by every nation to proceed together gearing to confirm that not even a single one of them is left alone.

\subsubsection{Seventeen SDGs}

These abovementioned sustainable development goals encompass:

1) Poverty Eradication 
2) No Starvation

3) Work for Health and Welfare

4) Standard Pedagogy

5) Gynic Equity

6) Hygienic Water alongside Cleanliness

7) Low-cost and Immaculate Energy

8) Reasonable Toil and Lucrative Amelioration

9) Business, Revolution, and Architecture

10) Minimized Disproportions

11) Maintainable Towns and Factions

12) Maintaining Weather Patterns

13) Tranquility, Impartiality and Inviolable Institutes

14) Collaborations for the aims

15) Aquatic Life

16) Life on Terrain

17) Sane Usage and Fertility
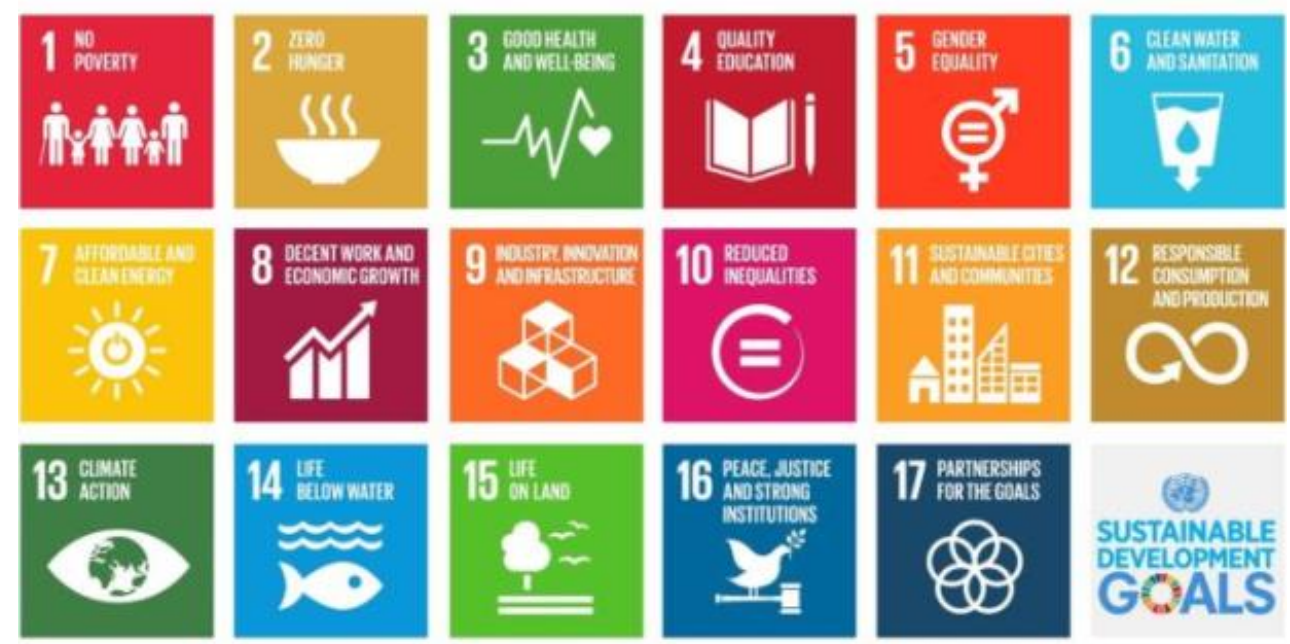

Figure IX 17 Sustainable Development Goals

\subsubsection{Work Done}

- Poverty has been reduced to half -- almost 800 million people even so earn less than a two dollars daily

- Starvation has been reduced as well - children suffering from malnutrition have been cut down to $24 \%$ in 2014 as from $33 \%$ in 2000 
- Death rate during and after child birth of mothers and babies as reduced - a by 2015 , worldwide mortality ratio during childbirth has cut down by $44 \%$, while death rate of children less than 5 years also dropped by more than $50 \%$

- Approach to hygienic imbibing water has been improved -- from 2000-2015 access to safe water wellsprings increased by $9 \%$ reaching the earmark of $91 \%$

- Adolescent marriages have been declined - proportion of marrying the girls less than 18 years reduced by $6 \%$ touching the range of $26 \%$ by 2015

- Countries are increasing their assistance - foreign assistance for the underdeveloped countries increased to 131.6 billion dollars by 2015 , showing an increase of $6.9 \%$ within a year

All of the seventeen targets are quite interconnected.

to water and sanitation services:

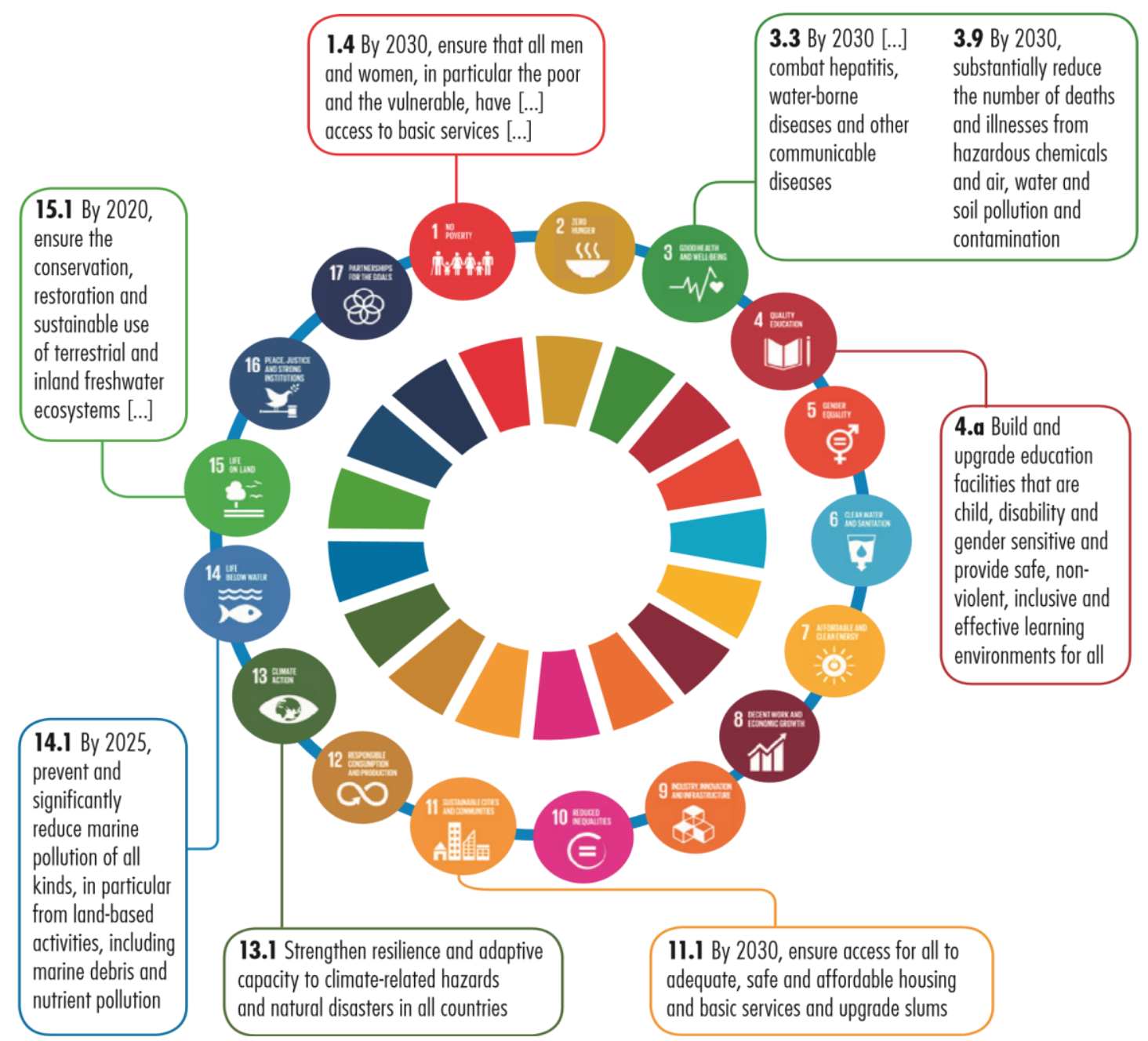

Figure X Correlation between 17 SDGs 


\subsubsection{SDG 06}

The sixth sustainable development goal is about clean water and hygiene or sanitation. As already mentioned, water inadequacy is affecting more than $40 \%$ population of the world, being quite alarming situation. And unfortunately, this situation is worsening day by day with the climate changes. Irrespective of the fact that a population of 21 billion people has got access to clean hygienic water and sanitation facilities since past two decades, still waning water wellsprings are influencing every continent.

Every year, another country is facing the issues like water inadequacy, and hence drought is ameliorating. By 2050, it was estimated that about one out of every four people will become a victim of water scarcity.

Achieving clean, and hygienic drinking water requires that the architecture of water wellsprings, sanitation resources, and water lines alongside the hygiene should be considered worthy to spend money on. Apart from that, water-affiliated biotic should be secured and reinstated.

Those 800 million people should be contacted for the availability of hygienic water who are deprived of the access to drinking water wellsprings, and fundamental services should be provided to them.

In 2015 alone by stats, about 4.5 billion population was suffering from inadequacy of safe management services regarding sanitation, and about 2.3 billion population required fundamental sanitation facilities.

\subsubsection{Uganda and SDG 06 in 2020 Evaluation}

Uganda showed little ameliorations in improving the drinking water wellsprings both in pastoral and town areas. Specifically pastoral areas showed an improvement of $4 \%$ in three year span of 2016-2019 with an estimate of 69\% from 65\%. While urban areas improved about $8 \%$. Ratio of hygiene water reservoirs supplied to the villages in Uganda increased from $64 \%$ to $69 \%$, clearly by $5 \%$ from $2017-2019$.

As mentioned many times above, Uganda is facing some serious water crisis despite of all the work done and ongoing by local and international organizations and governments. Apart from the water crisis threats of ameliorating contaminations, population, mechanization, cityscape, requirements of water-associated ecosphere, and the effects of weather changes are also some 
major upcoming issues for Uganda. And definitely, after such crisis going side by side, they have to double the yearly rate of progression.

In 2018, it was seen that Water \& Environment Sector Performance Measurement Framework (2016) had been started to execute. This execution also included emendation of the framework's twenty-two platinum and gold benchmarks just to integrate the sustainable development goals and more evolving issues deriving from the demand from even more firm standard water needs, ameliorated water and hygiene steps, standard administration, and weather variations.

Uganda declared that the country's government is currently concentrating on the targets by sustainable development goals point 06 , about water and sanitation. This is because, targets are increasing for the regions that were considered the least sufficed ones, to invoke the water sources which are not working, creating resources to help poor in the regions where salaries are very low, or are equal to the house tax. According to those statements, Ugandan government is also working on espousing the triple $\mathrm{R}$ technique. Triple $\mathrm{R}$ technique involves:

Recognizing - vigilance at the policies at group or house levels

Reducing - laborious works using the automated technology

Redistributing - domestic labor from females to males

By 2030, Uganda guaranteed safe and low-cost hygienic water for all the citizens. But this guarantee requires some financing in order to improve the standard and volume of water architectures, providing proper sanitary facilities, stimulating standard cleanliness conducts, and securing water-associated biospheres.

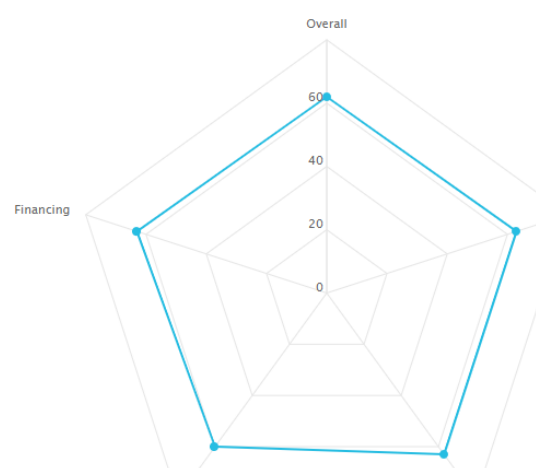




\subsubsection{Uganda's Stats by SDG 06 in 2020 About Clean Water and Sanitation}

Stats by sustainable development goals point 06 by 2020 are mentioned below:

- $7 \%$ population is exposed to safe drinking water

- $21 \%$ population has access to facilities regarding washing hand

- $5 \%$ population is treating the sewerage water safely

- $0 \%$ water estuaries in Uganda contain quality water

- $6 \%$ sustainable water resources are taken way after not meeting the environmental flow requirements

- $62 \%$ stats show the extent of execution of integrated water resource management (IWRM)

- $85 \%$ mutual valley area of Uganda has functional acceptance for water cooperation

- $-0.7 \%$ water-associated biosphere's structural area has changed

\subsubsection{Observing Clean Water and Asepsis Reports}

Table VIII Water supply technology resilience

\begin{tabular}{|l|l|l|}
\hline Instruments & Durability & Major Problems \\
\hline Driven wells & More & $\begin{array}{l}\text { Automatic pushing may pose challenge in dehydrating } \\
\text { surrounding }\end{array}$ \\
\hline $\begin{array}{l}\text { Hand Delved } \\
\text { wells }\end{array}$ & Less & $\begin{array}{l}\text { Issues with water standards; protecting year-round } \\
\text { provision is troublesome in some regions }\end{array}$ \\
\hline $\begin{array}{l}\text { Secured } \\
\text { springs }\end{array}$ & Less-modest & $\begin{array}{l}\text { Water standard threats from ameliorated rainfall and less } \\
\text { flow in dehydrating surroundings }\end{array}$ \\
\hline $\begin{array}{l}\text { Ménage roof } \\
\text { procedures }\end{array}$ & Less & $\begin{array}{l}\text { Lesser frequency with acute rain and dehydrating } \\
\text { surroundings give rise to menace }\end{array}$ \\
\hline $\begin{array}{l}\text { Channeled } \\
\text { water }\end{array}$ & Less & $\begin{array}{l}\text { Procedures are durable, but weather commuting can } \\
\text { ameliorate production conditions }\end{array}$ \\
\hline
\end{tabular}

Table IX Sanitation technology resilience

\begin{tabular}{|l|l|l|}
\hline Instruments & Durability & Major Problems \\
\hline
\end{tabular}




\begin{tabular}{|c|c|c|}
\hline Hole toilets & More & $\begin{array}{l}\text { Many modifications plausible; surging is a specific } \\
\text { provocation }\end{array}$ \\
\hline $\begin{array}{l}\text { Infected } \\
\text { panzers }\end{array}$ & Less-modest & At risk to surging and dehydrating surrounding \\
\hline $\begin{array}{l}\text { Improved } \\
\text { effluents }\end{array}$ & Modest & $\begin{array}{l}\text { Less endangered than traditional effluents to less water } \\
\text { amount, still surging a provocation }\end{array}$ \\
\hline $\begin{array}{l}\text { Traditional } \\
\text { effluents }\end{array}$ & Less-modest & $\begin{array}{l}\text { Threat from less water accessibility and surging of merged } \\
\text { gutters }\end{array}$ \\
\hline $\begin{array}{l}\text { Effluent } \\
\text { ministrations }\end{array}$ & Less-modest & $\begin{array}{l}\text { Endangered to escalations and dwindles in water; } \\
\text { ministration needs can escalate as transporting amplitude } \\
\text { gets lesser }\end{array}$ \\
\hline
\end{tabular}

\section{CHAPTER 4}

\section{IMPLEMENTATIONS AND IMPROVEMENTS}

\section{(Tsimpo and Wodon 2019)}

An international organization named World without Borders (WWB) implemented certain infrastructures in rural and urban areas of Uganda. Infrastructures that are being imposed are:

- Shallow wells

- Hand washing stations

- Water filters

Certain awareness campaigns were also taken in notice that helped the locals to get knowledge about hygiene.

- Health education

- Latrines improvement campaigns

\subsection{Shallow Wells}

Two shallow wells were dug and constructed in association with the local water engineers. These wells were constructed in the regions which were most for granted. These were thoughtfully made near the conventional wellsprings having little high water table. The depth of these wells was approximately $5 \mathrm{~m}$. Unfortunately, the engineer noted it wrongly as 4.5 meters. 


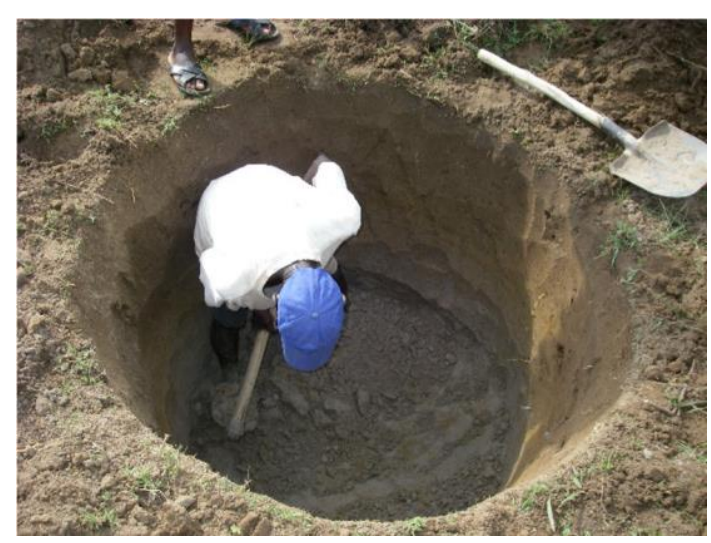

(a)

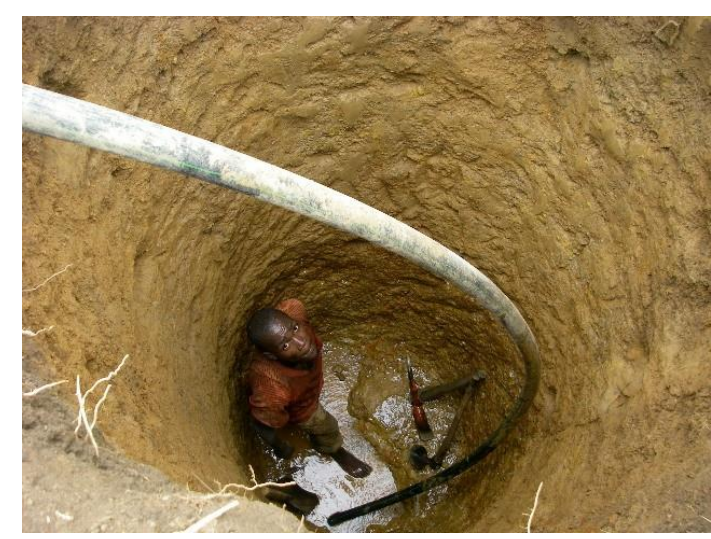

(b)

Figure XII Spading Shallow Wells

One of the major benefits of these wells is that they were quite affordable and they were able to get fixed by the locals and the local ware parts easily. The taps connected to them were of about 154 US Dollars each, making almost 300,000 Ugandan Shillings. The other charges including labor, transport, and installing them cost 590,000 local Shillings each.

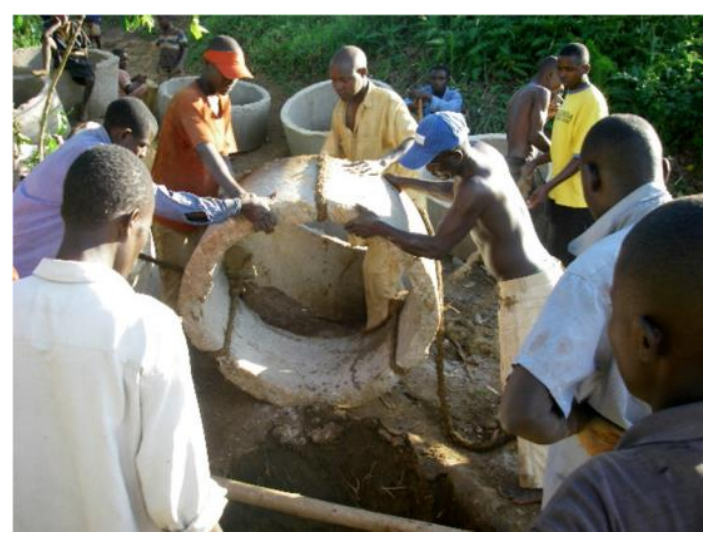

(a)

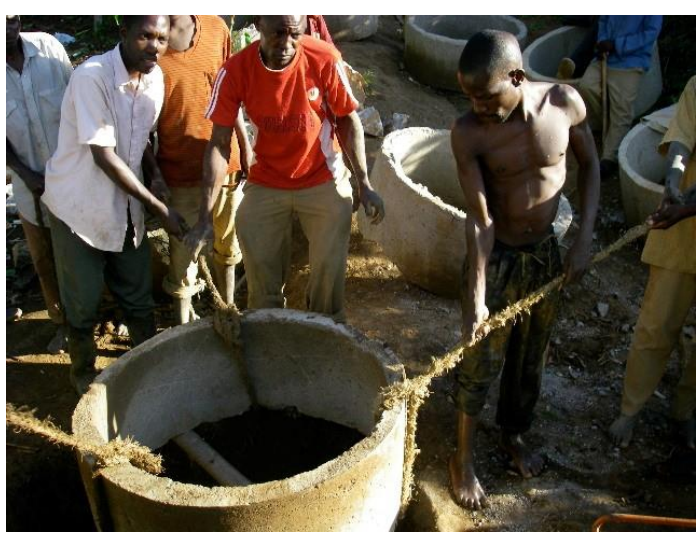

(b)

Figure XIII Greying the hefty culvrets

\subsection{Sanitation Terminals}

Approximately, 145 terminals for washing hands have been constructed, which are easy to make using local wares. They have the capacity to store little water but are easy to regularize. 


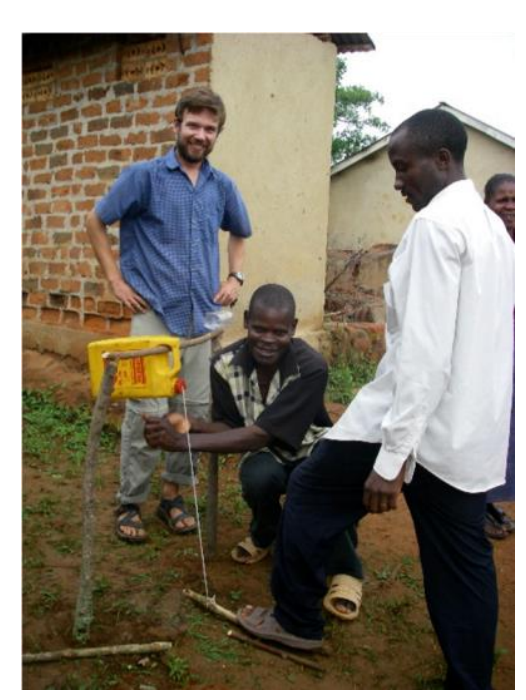

(a)

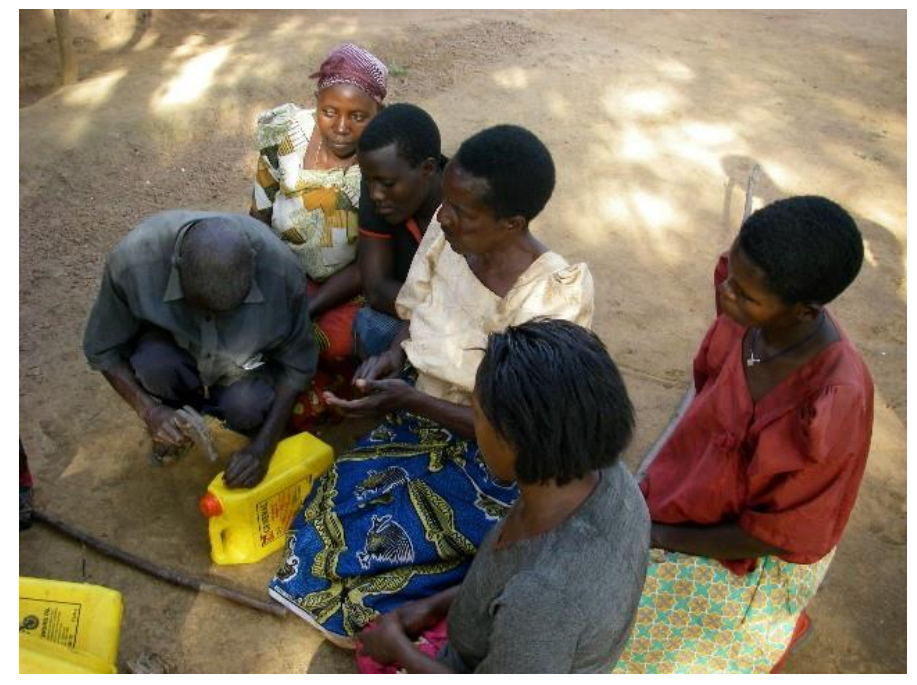

(b)

Figure XIV Tippy taps Conduction

\subsection{Water Filters}

Water filters were fixed in about 26 houses. They were ordered from Center for Affordability Water and Sanitation (CAWST) in Kampala.

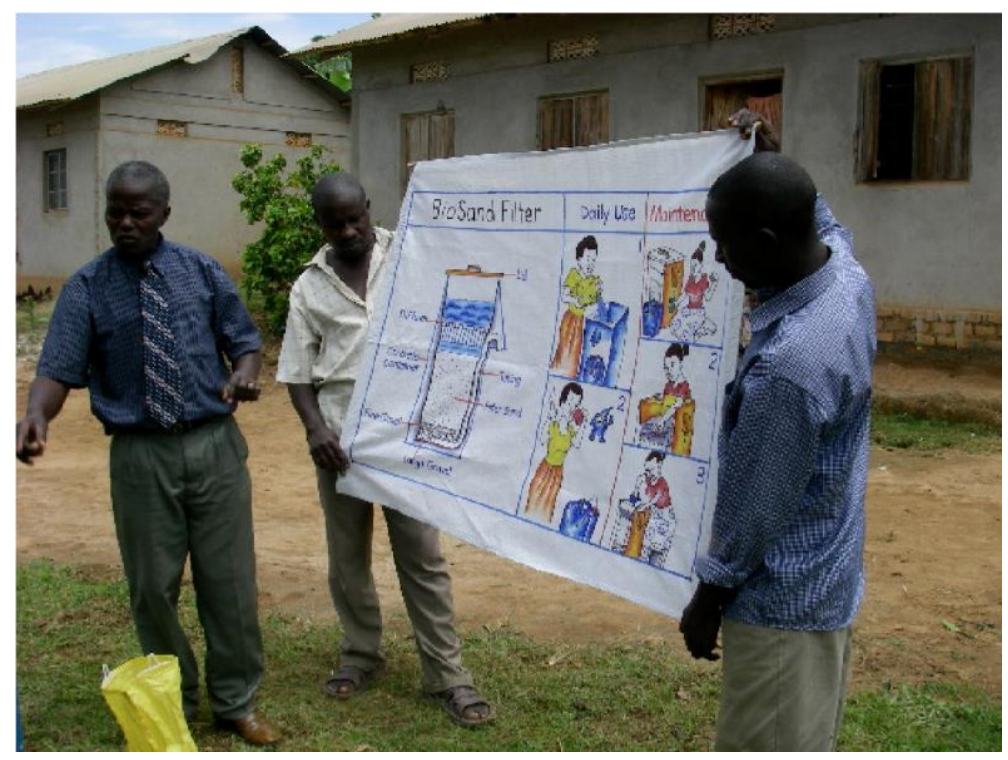

Figure XV Description of Filter Operation

\subsection{Health Education}

Health education campaigns were raised in Manyama, after various intercession, utilizing the dramas. General health topics were focused more. 


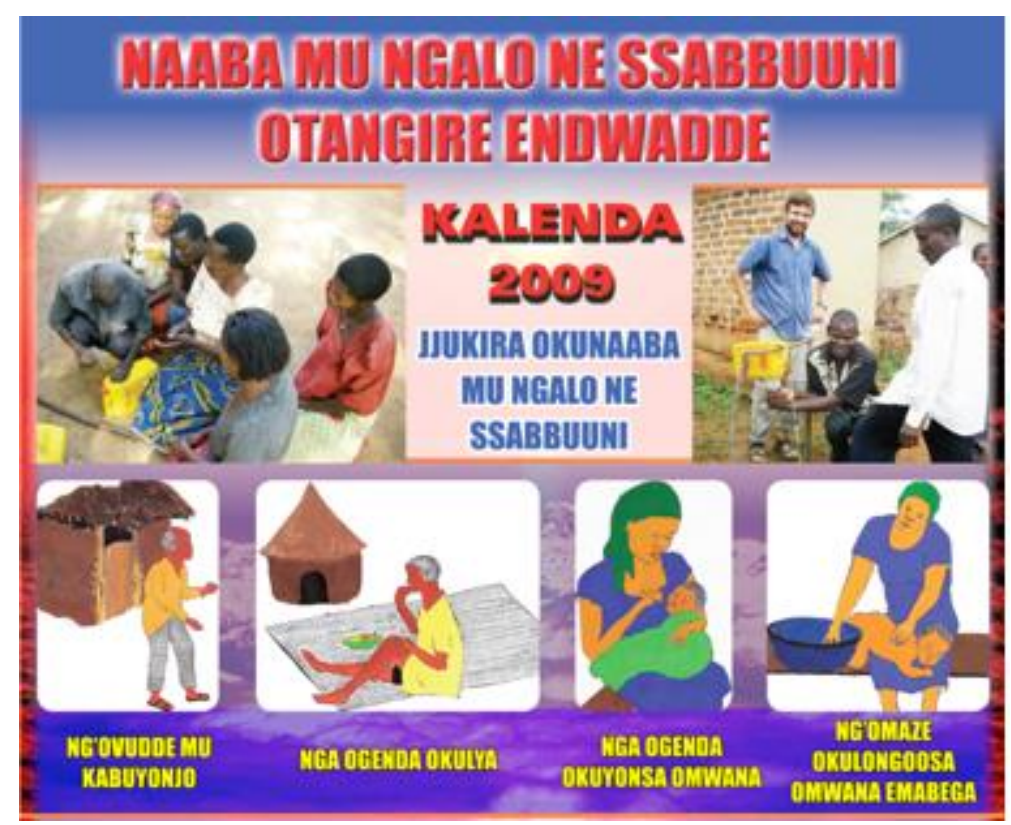

Figure XVI Title Page of Calendar

\subsection{Latrines Improvement Campaigns}

This campaign was based on the formation of slabs for those houses who used holes to throw out the excretions. 5 masons were instructed by one skilled artisan for designing the outlines. Apart from that, an endorsement movement was also done by the community health subjects, in order to motivate the locals to regularize these new toilets, clean them, ensuring that they are covered, and hand washing requirements are also placed near these toilets.

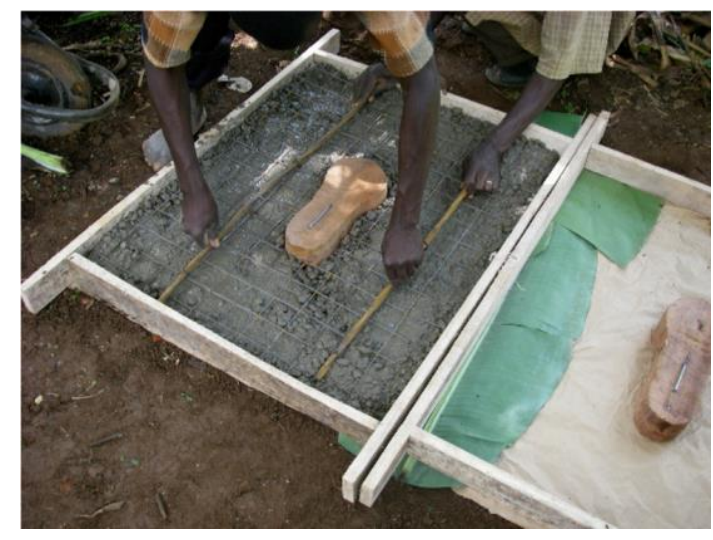

(a)

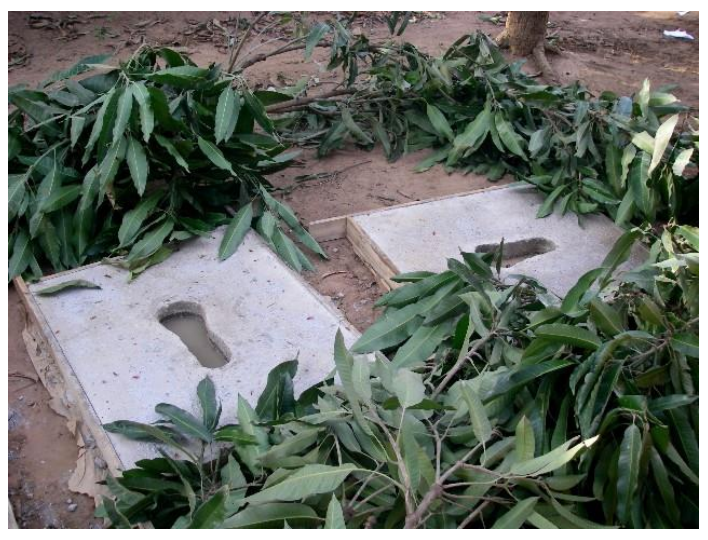

(b)

Figure XVII Latrine Slabs 


\section{CHAPTER 5}

\section{OUTCOMES \& ANALYSIS}

\subsection{OUTCOMES}

It was a literature-based survey.

Below are some visuals that can graphically explain the results of the discussions done in the entre research:
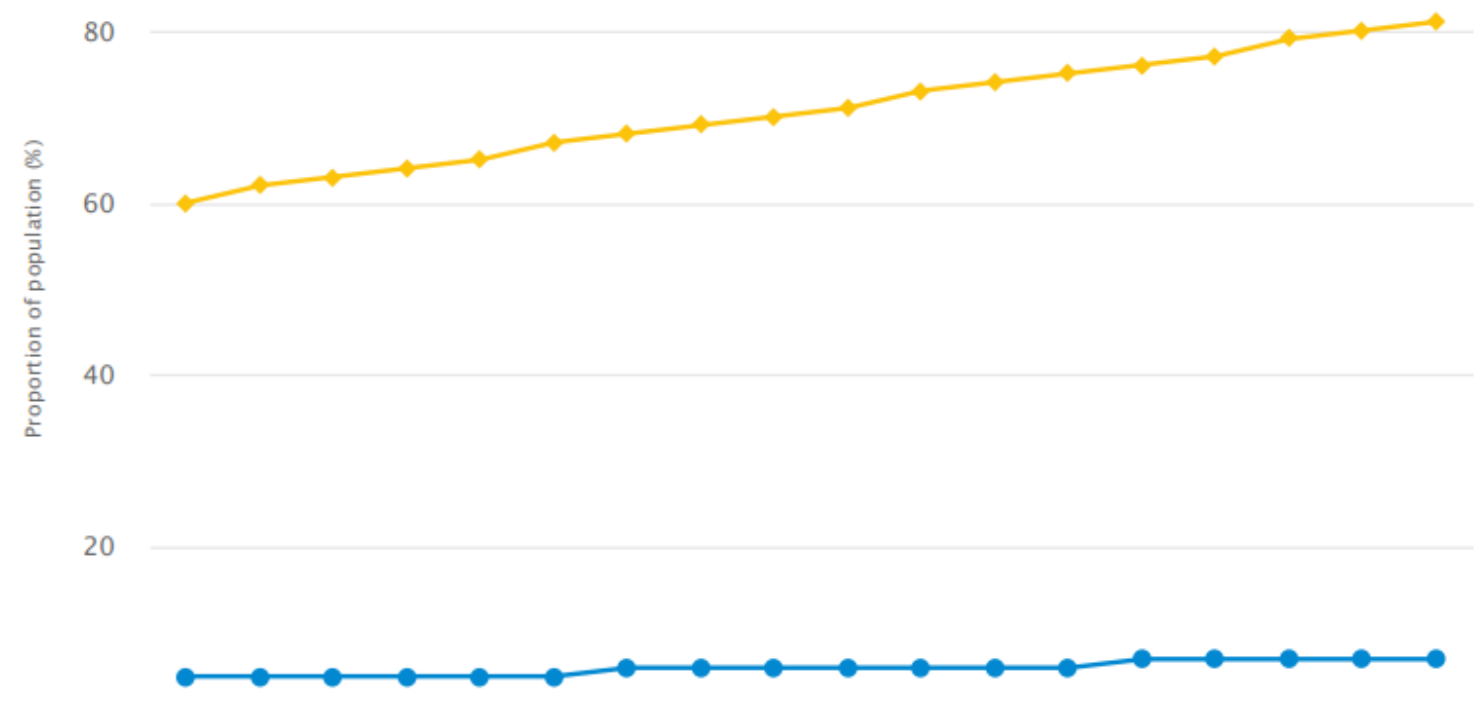

0

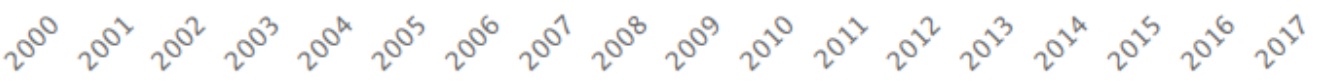

6.1.1 Proportion of population using safely managed drinking water service (\%) - Safely managed service Proportion of population using an improved drinking-water source (\%) - Total

Figure XVIII Ratio of Population using Drinking Water Services Overtime 


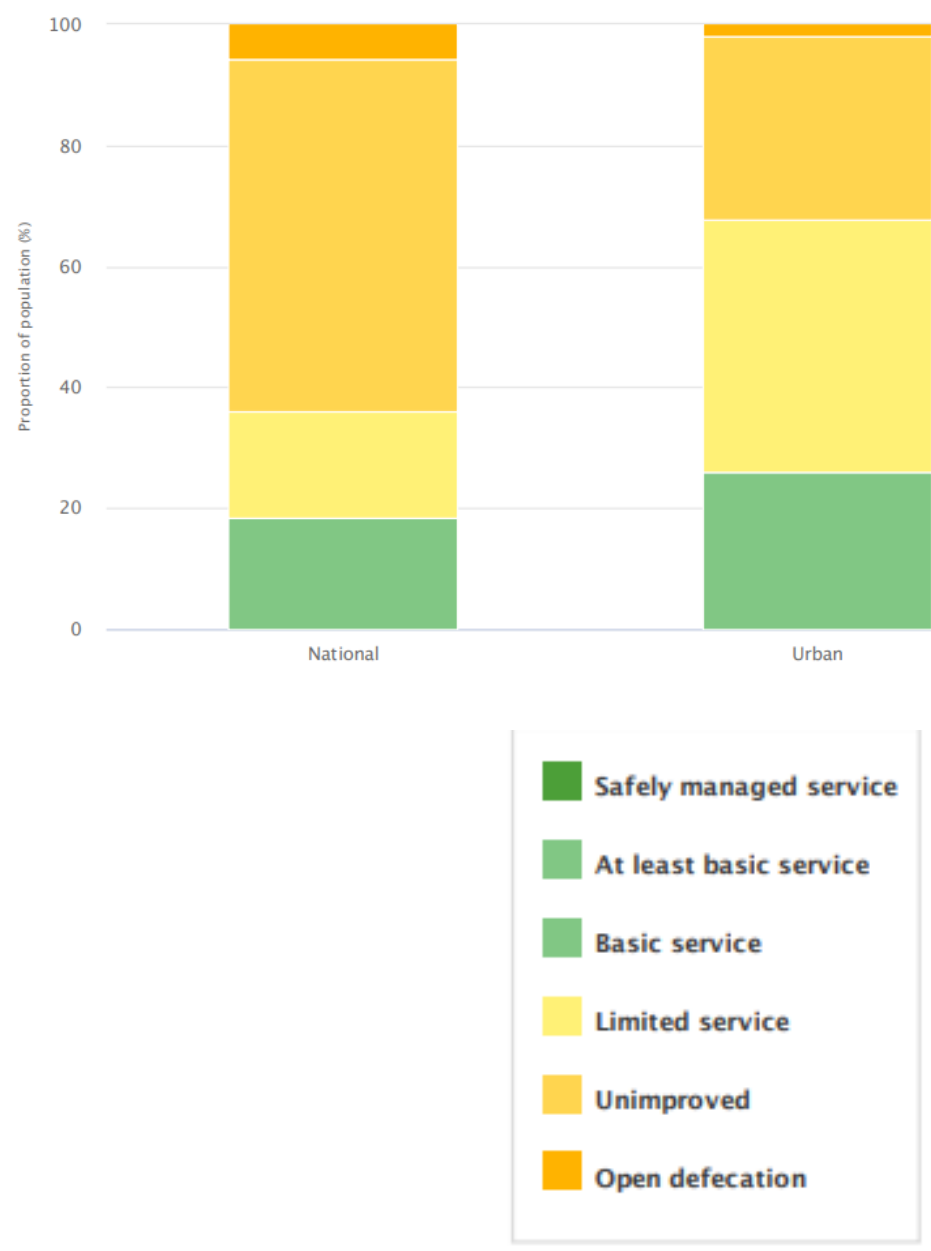

Figure XIX Ratio of Population using Sanitary Services

\subsection{CONCLUSIONS \& FURTHER RESEARCH}

The report completely describes the condition of water and hygiene in Uganda and especially its rural areas. Also what kind of improvements are needed in the architecture and infrastructure to make the lives of the citizens much better as they are now, are mentioned.

As seen in the data, locals utilize particular volume of water irrespective of the distances they find to travel in order to reach the water points and fetch the water to their homes after a long time of waiting there for their turns. No difference in the utilization of water was seen. Despite of all these things, one important point to be noted was that, rural Ugandans practiced hygiene conduct both in terms of themselves and the utensils they used for cooking and eating. And hence, they utilized more water, irrespective of the distance and time, just to fulfill their needs. Despite all these circumstances, a breath of fresh air is the climate of Uganda. It is bestowed with a modest weather, with adequate rainfall and a number of natural resources as well. 
Socio-economic status reputation was one of the factors that created a relationship with the water usage. More because those with lofty socioeconomic reputation, as quantified by the house, lifestyle and educational ranks, are linked with more understanding of cleanliness, and hygiene conduct. Ugandan schools do train about tidiness and environmental health. Another relationship between house area and per head utility was found.

Concluding the report in short, this document emphasizes on the water and hygiene ameliorations that must be practiced and regularized to assure the health, safety and economic growth of the Ugandans. Every sort of effort from ensuring the hygiene practices to improvising the infrastructure alongside teaching the locals about cleanliness should be made. Apart from that, intercessions about providing secure water wellsprings as near to the houses as possible is also necessary and should not be ignored. This can reduce the heavy impacts on health and also ameliorate lifestyle. (Tsimpo and Wodon 2019) 


\section{REFERENCES}

1. (2009). "Increasing Functional Sustainability of Water and Sanitation Supplies in Rural Sub-Saharan Africa." Environmental Engineering Science 26(5): 1017-1023.

2. Cairncross, S. and J. Cuff (1987). "Water use and health in Mueda, Mozambique." Transactions of the Royal Society of Tropical Medicine and Hygiene 81(1): 51-54.

3. Cairncross, S. and R. Feachem (1993). Environmental health engineering in the tropics: an introductory text, John Wiley \& Sons Ltd.

4. Esrey, S. A. and J.-P. Habicht (1986). "Epidemiologic evidence for health benefits from improved water and sanitation in developing countries." Epidemiologic reviews 8(1): 117-128.

5. Etongo, D., G. Fagan, C. Kabonesa and R. Asaba B (2018). "Community-managed water supply systems in rural Uganda: The role of participation and capacity development." Water 10(9): 1271.

6. Fewtrell, L., R. B. Kaufmann, D. Kay, W. Enanoria, L. Haller and J. M. Colford Jr (2005). "Water, sanitation, and hygiene interventions to reduce diarrhoea in less developed countries: a systematic review and meta-analysis." The Lancet infectious diseases 5(1): 42-52.

7. Howard, G., J. Bartram, A. Williams, A. Overbo, J.-A. Geere and W. H. Organization (2020). Domestic water quantity, service level and health, World Health Organization.

8. Marijani, R. (2017). "Community Participation in the Decentralized Health and Water Services Delivery in Tanzania." Journal of Water Resource and Protection Vol.09No.06: 20.

9. Marks, S. J., G. Clair-Caliot, L. Taing, J. T. Bamwenda, C. Kanyesigye, N. E. Rwendeire, J. S. KemerinkSeyoum, F. Kansiime, D. W. Batega and G. Ferrero (2020). "Water supply and sanitation services in small towns in rural-urban transition zones: The case of Bushenyi-Ishaka Municipality, Uganda." npi Clean Water 3(1): 21.

10. Mugumya, F. (2013). Enabling community-based water management systems: Governance and sustainability of rural point-water facilities in Uganda, Dublin City University.

11. Richmond, A., I. Myers and H. Namuli (2018). "Urban Informality and Vulnerability: A Case Study in Kampala, Uganda." Urban Science 2(1): 22.

12. Tsimpo, C. and Q. Wodon (2019). Water and Sanitation in Uganda, World Bank Publications.

13. WELL. and G. B. D. f. I. Development (1998). Guidance manual on water supply and sanitation programmes, WEDC, Loughborough University.

14. Zwane, A. P. and M. Kremer (2007). "What works in fighting diarrheal diseases in developing countries? A critical review." The World Bank Research Observer 22(1): 1-24.

15. (2009). "Increasing Functional Sustainability of Water and Sanitation Supplies in Rural Sub-Saharan Africa." Environmental Engineering Science 26(5): 1017-1023.

16. Nilsson, D. (2006). "A heritage of unsustainability? Reviewing the origin of the large-scale water and sanitation system in Kampala, Uganda." Environment and Urbanization 18(2): 369-385. 
17. Tumwine, J. K., J. Thompson, M. Katua-Katua, M. Mujwajuzi, N. Johnstone, E. Wood and I. Porras (2002). "Diarrhoea and effects of different water sources, sanitation and hygiene behaviour in East Africa." Tropical Medicine \& International Health 7(9): 750-756.

18. Richmond, A., I. Myers and H. Namuli (2018). "Urban Informality and Vulnerability: A Case Study in Kampala, Uganda." Urban Science 2(1): 22.

19. Marks, S. J., G. Clair-Caliot, L. Taing, J. T. Bamwenda, C. Kanyesigye, N. E. Rwendeire, J. S. KemerinkSeyoum, F. Kansiime, D. W. Batega and G. Ferrero (2020). "Water supply and sanitation services in small towns in rural-urban transition zones: The case of Bushenyi-Ishaka Municipality, Uganda." npj Clean Water 3(1): 21.

20. Marijani, R. (2017). "Community Participation in the Decentralized Health and Water Services Delivery in Tanzania." Journal of Water Resource and Protection Vol.09No.06: 20. 